\title{
VARIOUS COMPETITIVE LEVEL WRESTLERS' PREPAREDNESS ASSESSED BY THE APPLICATION OF THE FIELD TEST
}

\author{
Marković R. Milan ${ }^{1}$, Goran Kasum², Milivoj Dopsaj², Lazar Toskić3 $^{3}$, Ivan Zarić ${ }^{1}$ \\ ${ }^{1}$ University of Belgrade, Faculty of Sport and Physical Educatiom, student DAS, Serbia, \\ ${ }^{2}$ University of Belgrade, Faculty of Sport and Physical Educatiom, Serbia \\ ${ }^{3}$ University of Prishtina, Faculty of Sport and Physical Education, Leposavić, Serbia
}

\begin{abstract}
Wrestling is a sport which is dominantly characterized by physical strains in anaerobically lactate energy zones. The subject of this work are the parameters of wrestlers' preparedness, from the viewpoint of their success, as well as the level of metabolic and cardiac reaction of an organism, observed on the specific field test. The aim of the research is to determine the differences in the levels of specific preparedness between different competitive levels of wrestlers. The sample consists of 26 wrestlers, divided into two groups in relation to a competitive level they perform on, i.e. 10 of them perform in the First League of Serbia, while 16 perform in the Second Wrestling League of Serbia. Specific Wrestling Performance Test (SWPT) consists of two 3-minute segments, which stimulate rounds in a fight timewise, and between which there is a 30-second rest. In order to relativize the load, three different weight wrestling dummies were used, and the suplex technique as the standard throw for all examinees. General differences have been determined by MANOVA test, whereas individual differences of all variables have been determined by the $t$ test in the function of the examined groups. Based on the results, and in the function of the models for calculating the parameters of the specific preparedness of wrestlers, the statistically significant difference $(\mathrm{p}=0.000)$ of the achieved

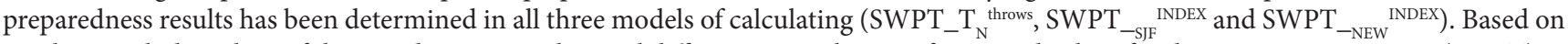
similar metabolic values of the tested groups, and partial differences in achieving functional values for the same given exertion (SWPT), it can be concluded that the determined differences of all three models for calculating the preparedness parameters of the examined groups are the consequence of insufficient adaptation for high load realization, which requires high pulse frequency as well as lactate concentration and the given time period.
\end{abstract}

Key words: WRESTLING / MEASURING / FIELD TESTING / RECOVERY / SUCCESS INDEX

\section{INTRODUCTION}

Wrestling requires high level of technical, tactical and psychological abilities and skills development (Hubner-Wozniak et al., 2006). Generally, all energy systems work simultaneously (aerobic and anaerobic) but in the different degree of representation which always depends on the energy requirements of the current technical and tactical situation of the fight (Cinar \& Tamer, 1994; Callan et al., 2000). In previous research, it has been determined that decisive fights happen in the zones of maximal and submaximal load of a wrestler (Nilsson et al., 2002; HubnerWozniak et al., 2004).
Some authors have estimated that up to $90 \%$ of energy needs in a wrestling fight is provided from anaerobic sources, i.e. the anaerobic glycolytic pathways mostly prevail in a fight (Hubner-Wozniak et al., 2006; Karninčić et al., 2009). As such, wrestling is a sport which is dominantly characterized by physical strains in anaerobic metabolic energy zones. The anaerobic system provides metabolic conditions for short and quick execution of maximum strength during a fight, for sudden and explosive throws and lifts, but also for leading a fight with submaximal and maximal intensity, while aerobic system contributes 
to wrestler's ability to maintain moderate,middle and smallefforts during a fight. The studies have shown that the general physiological profile of a successful wrestler is the high anaerobic strength and capacity, as well as above average aerobic power, high percentage of muscle mass and highly developed muscle strength, exceptional flexibility, low percentage of fat (Horswill, 1992; Kasum \& Dopsaj, 2012; Yoon, 2002).

Diagnostics of physical characteristics is an important part of the control process of being welltrained and well-taught as it provides information on the ability which needs to be improved, but on the efficiency of training process applied as well (Lidor et al., 2006). Special attention in wrestler's performance diagnostics should be paid to anaerobic and lactate energy systems. As a result of dominant representation of this energy system in competitive wrestling, high to maximum values of pulse frequency are achieved (Kraemer et al., 2001). Also, moderate to exceptionally high lactate concentration is accumulated (10-20 $\mathrm{mmol} / \mathrm{L}$ ) after the competition (Houston et al., 1983; Kraemer et al., 2001) which can cause acid-base imbalance and lead to performance deterioration (Aschenbach et al., 2000). By observing these metabolic and contractile characteristics during intensive training or competition of athletes, the levels of acidosis and muscle fatigue, as well as the parameters of athlete's general preparedness can be evaluated (Barbas et al., 2010; Karninčić et al., 2009; Nilsson et al., 2002; Wright et al., 2015).

The method of field testing is a way of testing which enables coaches to check the level of an athlete's current preparedness in relation to the specific load conditions. In other words, specific tests present the approximation of sports activity to controlled conditions, which is possible to observe and measure, and which simulate the time structure of competition, i.e. fight, as well as load, metabolic and cardiac exertion that are manifested during competition fights (Maglischo, 2003; Muller et al., 2000; Zatsiorsky, 1982).

In relation to these aspects, it is not possible to find a vast number of research that deal with the specific field testing in wrestling, i.e. the specific preparedness and body's response to given exertion (Utter et al., 1997; Marković et al., 2017). In relation to the published scientific literature available, larger number of works has dealt with metabolic and functional reactions of the organism in the real wrestling fight
(Karninčić et al., 2009; Barbas et al., 2010; Karninčić et al., 2013; Arslanoğlu et al., 2015), i.e. in laboratory or field tests which were designed in relation to the non-specific wrestling tasks (Callan et al., 2000; Wright et al., 2015).

The subject of this work are the parameters of wrestler's preparedness from the aspect of their success, as well as the level of organism's metabolic and cardiac reaction on the applied test. The aim of the research is to determine the differences in the level of specific preparedness between the wrestler of the First and the Second Wrestling League of Serbia. The difference in competition levels in which the tested groups performed imposes an expectation that the $1^{\text {st }}$ league would achieve better results than the $2^{\text {nd }}$ wrestling league, i.e. confirm that the physical preparedness is an important factor in wrestling. The results obtained in this research can be used for the purpose of further research, their mutual comparisons, as well as for the improvement of the already existing results, i.e. for the purpose of increasing general and specific knowledge fundus in wrestling and in sports science in general.

\section{METHOD}

As the primary method of researching, the field testing method has been used. As the primary cognitive method, the analytical method has been applied, as well as the induction method. In relation to analytical methods, the method of functional analysis has been applied in order to discover mutual relations and connections of the parts of the examined phenomenon, as well as comparative analysis in order to compare traits, similarities and patterns of the repetition of executed performances.

\section{Research sample}

The sample consists of 26 male wrestlers, divided into two groups in the function of competitive success. From the total number of sample, 10 wrestlers perform in the First League of Serbia $-1^{\text {st }}$ League (age: 20.0 years; sports experience: 8.4 years; number of trainings per week: 9.2; body height: $176.0 \mathrm{~cm}$; body weight: $78.0 \mathrm{~kg}$; BMI: $25.46 \mathrm{~kg} / \mathrm{m}^{2}$; body fat percentage: $12.02 \%$; muscle mass percentage: 48.94 
$\%)$, while 16 wrestlers perform in the Second League of Serbia $-2^{\text {nd }}$ League (age: 20.4 years; sports experience: 5.6 years; number of trainings per week: 7.0; body height: $180.9 \mathrm{~cm}$; body weight: $85.3 \mathrm{~kg}$; BMI: $26.10 \mathrm{~kg} / \mathrm{m}^{2}$; body fat percentage: $14.80 \%$; muscle mass percentage: $49.01 \%)$. All examinees were familiar with the testing conditions and voluntarily participated in the research. The research was carried out according to the conditions of Declaration of Helsinki, with the approval and consent of the Faculty of Sport and Physical Education University of Belgrade's Ethics Committee.

\section{Measuring procedure}

The body composition measuring was carried out by bioelectrical impedance (InBodi 720 Biospace, 2008), in the morning from 08:00 - 09:00 am, in accordance with the standardized recommendation of the manufacturer. A light meal ensued afterwards (fruit or a smaller sandwich, along with rehydration), as well as the 1-hour break, after which the examinees were tested in the wrestling gym. The beginning of measuring the specific field test was around 10 oclock a.m. The afore mentioned tests were carried out at the Faculty of Sport and Physical Education, University of Belgrade.

For the needs of the specific wrestling test, all examinees were tested by applying the measuring procedure which had been standardized beforehand (Marković et al., 2017), which all examinees were familiar with during the last training before the testing. On the testing day, all examinees went through the process of final theoretical and practical familiarization with the procedure of the task. Before the testing, wrestlers did a general 15-minute warm-up individually, followed by additional 5 minutes of specific warm-up in the form of throwing a partner or a wrestling dummy, after which a 10-minute break ensued.

On the wrestling test, a wrestling dummy was used as a prop and the suplex techniqueas the standard throw for all examinees. In order to relativize the load, three dummies with different weights were used as follows: $\leq 74.9 \mathrm{~kg}$ body weight, a $22 \mathrm{~kg}$ dummy was thrown, from 75.0 to $89.9 \mathrm{~kg}$, a $27 \mathrm{~kg}$ dummy was thrown, and $\geq 90.0 \mathrm{~kg}$, a $32 \mathrm{~kg}$ dummy was thrown (Marković et al., 2017).
The testing procedure itself was realized in the form of a controlled task through precisely marked task time for which a special software, programmed according to the task's time structure of the test, was used. Also, apart from the auditive signals which denote preparation, beginning and end of the test, the examinees were provided with the visual display and time control as well as a display of every segment of the test. Time intervals of work and rest, as well as the intensity of work according to the scheme presented with the Table 1 . constructed the time and motoric structure of the tests as follows:

\section{"Specific Wrestling Performance Test”(SWPT)}

The test consists of two 3-minute segments, which simulate a round in a fight timewise, with a 30 -second rest between each segment. The task was as follows: after the commencement of the test is signaled, the examinee throws the dummy, then lifts the dummy into the initial position and rests until the 10th second elapses, then realizes the throw again, lifts the dummy and rests until the 20th second elapses, and ultimately, realizes the throw and rests until the 30th second elapses. Once the stopwatch ticks the 30th second, the intensive part of the test ensues - a part where the examinee's task is to realize as larger number of throws as possible in the next 20 seconds; from the 50th to the 60th second, the examinee rests and prepares for the second minute of the test which is completely the same as the first one; in the third minute of the test, up until the 30th second, everything is the same, and afterwards, the examinee realizes as larger number of throws as possible in the 30 -second timeframe, the second round of the test is completely the same as the first (Marković et al., 2017). In addition to performing the given throws in 10-second intervals, the general task of the examinee was also to realize the largest number of throws possible in the phases defined for the maximum number of throws. The total number of throws realized in the phases for performing the maximum number of throws achieved during the entire test, i.e. both rounds, is taken as the final result of the test (Table 1). 
Table 1. Structure Specific Wrestling Performance Test (SWPT) (Marković et al., 2017).

\begin{tabular}{|c|c|c|c|c|c|c|c|c|c|c|c|c|c|c|c|}
\hline \multicolumn{16}{|c|}{ Structure: Specific Wrestling Performance Test / Test duration: 6 minutes 30 seconds } \\
\hline \multirow{3}{*}{$\begin{array}{c}\text { Rounds } \\
\text { FIRST round }\end{array}$} & \multirow{2}{*}{$\begin{array}{c}\text { Minutes: } \\
\text { t. intervals (s) }\end{array}$} & \multicolumn{5}{|c|}{1 minute } & \multicolumn{5}{|c|}{2 minutes } & \multicolumn{4}{|c|}{3 minutes } \\
\hline & & 10 & 10 & 10 & 20 & 10 & 10 & 10 & 10 & 20 & 10 & 10 & 10 & 10 & 30 \\
\hline & Number of throws & 1 & 1 & 1 & Max. & Rest & 1 & 1 & 1 & Max. & Rest & 1 & 1 & 1 & Max. \\
\hline \multicolumn{2}{|c|}{ rest (s) } & \multicolumn{14}{|c|}{30} \\
\hline \multirow{2}{*}{ SECOND round } & t. intervals (s) & 10 & 10 & 10 & 20 & 10 & 10 & 10 & 10 & 20 & 10 & 10 & 10 & 10 & 30 \\
\hline & Number of throws & 1 & 1 & 1 & Max. & Rest & 1 & 1 & 1 & Max. & Rest & 1 & 1 & 1 & Max. \\
\hline
\end{tabular}

\section{Variables}

Apart from the variables which define the number of throws per individual test segments $(20 \mathrm{sec}$. intended for the maximum number of throws in the first minute of the first round of the test - SWPT_I_ $\mathrm{A}^{\text {throwes }}, 20 \mathrm{sec}$. intended for the maximum number of throws in the second minute of the first round of the test - SWPT_I_B ${ }^{\text {throwes }}, 30$ sec. intended for the maximum number of throws in the third minute of the first round of the test - SWPT_I_C $C^{\text {throwes }}, 20 \mathrm{sec}$. intended for the maximum number of throws in the first minute of the second round of the test - SWPT_ II_A ${ }^{\text {throwes }}, 20 \mathrm{sec}$. intended for the maximum number of throws in the second minute of the second round of the test - SWPT_II_B ${ }^{\text {throwes }}, 30 \mathrm{sec}$. intended for the maximum number of throws in the third minute of

the second round of the test - SWPT_II_C $\left.{ }^{\text {throwes }}\right)$, the total number of throws on the test has been defined as well (SWPT_ $\mathrm{T}_{\mathrm{N}}{ }^{\text {throws }}$ ) which represents a one-dimensional model for evaluating the wrestler's preparedness.

Apart from the one-dimensional model for evaluating preparedness, which from the viewpoint of information complexity is the simplest variant of calculation, additional two models were used as the criteria variables of specific preparedness.

The two-dimensional model for calculating preparedness $\left(\mathrm{SWPT}_{-\mathrm{SJF}}^{\text {INDEX }}\right.$ ) apart from the maximum number of throws, includes the values of achieved heart rate directly after and during the first minute of recovery, and its principle of calculating was taken from the Specific Judo Fitness Test (Franchini et al., 1998), and is calculated using the following formula:

$$
\left.{ }_{\mathrm{SJF}}^{\mathrm{INDEX}}=\left(\mathrm{HR}^{0 \mathrm{~min} . \cdot}+\mathbf{H R}^{1 \mathrm{~min} .}\right) / \mathrm{T}_{\mathrm{N}}^{\text {throws }} \text { (lower value means better result }\right) .
$$

The three-dimensional model for calculating preparedness (SWPT ${ }_{-\mathrm{NEW}}$ INDEX), apart from the total number of throws and values of achieved heart rate, includes the values of measured lactate concentrations in the $3^{\text {rd }}$ and $5^{\text {th }}$ minute of recovery. This principle

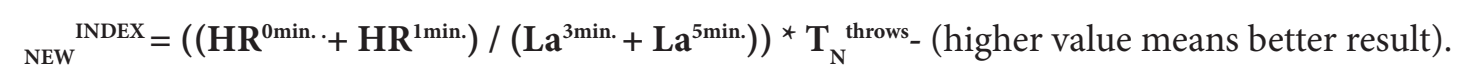

Certainly, metabolic and cardiac parameters were observed as well, as individual parameter variables of the total physiological strain achieved on the test (Astrand et al., 2003) as follows:

- Lactate concentration in capillary blood as a means of achieved metabolic acidosis, in the third (SWPT_La ${ }^{3 \mathrm{~min}}$ ) and the fifth (SWPT_ $\mathrm{La}^{5 \mathrm{~min} .}$ ) minute of recovery, expressed in $\mathrm{mmol} / \mathrm{L}$; of calculating the wrestler's preparedness index represents the new model of calculating which was published by Markovic et al. (2017), and is calculated using the following formula: 
Upon finish of the test, wrestlers had 1 minute of active rest, after which they took the next position in order to measure the achieved lactate concentration in blood and continue observing the heart rateparameters according to the standard procedure. $\mathrm{H} 7$ Polar Heart Rate Sensor (Polar, Inc., Lake Success, NY, USA) which was placed around the chest of the examinee before the test, was used to measure the frequency of the pulse.The lactate concentration was analyzed using a portable new generation lactate analyzer (Lactate Plus-NOVA biomedical, USA), using a lactate biosensor based on lactate oxidization (Lactate Methodology - Lactate oxidase biosensor) (Hart et al., 2013; Kulandaivelan et al., 2009).The samples were collected from the capillary blood, each time from a different finger by an experienced research (Dopsaj \& Janković, 2014; Marković et al., 2017). For the invasive part of collecting a blood sample, a single-use lancet Unistik 3 Comfort (Owen Mumford Ltd. UK) was used.

\section{Statistical procedures}

All results were firstly analyzed by applying the basic descriptive statistics where the following was calculated: measures of central tendency (mean variable value - Mean) and dispersion (standard deviation - Std. Dev., standard error - Std. Err., minimum - Min., maximum - Max.). General differences between groups were determined using MANOVA, while the significant differences of every individually tested variables were determined using $\mathrm{T}$ test. All statistical analysis were carried out using the software package SPSS 20.0, whereas the value $\mathrm{p}<0.05$ was used for the level of statistical significance of differences (Hair et al., 1998).

\section{RESULTS}

In Table 2, MANOVA test results are shown, based on which the general difference in preparedness parameters between the groups of different competitive level has been determined.

Table 2. Results of the differences on general level of examined (MANOVA).

\begin{tabular}{cccccccc}
\hline $\begin{array}{c}\text { Wilks' } \\
\text { Lambda }\end{array}$ & Value & $\mathrm{F}$ & Hypothesis df & Error df & Sig. & $\begin{array}{c}\text { Noncent. } \\
\text { Parameter }\end{array}$ & $\begin{array}{c}\text { Observed } \\
\text { Power }\end{array}$ \\
\cline { 2 - 9 } & 0,031 & 17,307 & 16,000 & 9,000 & $\mathbf{0 , 0 0 0}$ & 276,908 & 1,000 \\
\hline
\end{tabular}

Based on results achieved on SWPT, in relation to individual minutes of the test, i.e. predicted period for maximum number of throws (SWPT_I_A ${ }^{\text {throwes, }}$ SWPT_I_B $B^{\text {throwes }}$, SWPT_I_C $C^{\text {throwes }}, S W P T$ II_A $A^{\text {throwes }}$, SWPT_II_B ${ }^{\text {throwes }}$, SWPT_II_C $\left.C^{\text {throwes }}\right)$, the difference of the achieved results, whichrange from $25.2 \%$ to $35.2 \%$ in the function of examined groups, has been determined in percentage. In relation to the total number of throws on the test (SWPT $\mathrm{T}_{\mathrm{N}}$ throws), the $1^{\text {st }}$ league achieved higher number of throws for 30.2 $\%$ (Figure 1; Table $3,1^{\text {st }}$ league $=43.60$ vs $2^{\text {nd }}$ league $=$ 30.44 ), whereas the achieved results on the test generally ranged from 24.0 to 47.0 throws.

In the function of the examined groups, heart rate response (HR) on the test reached percentual differences from $2.2 \%$ to $10.1 \%$ of pulse frequency in relation to the observed recovery variables of the cardiovascular system. Upon the finish of the test, the response to the given exertion ranged from 175 to 196, after a minute of recoveryfrom 153 to 184 , after the second minute of recovery from 131 to 167 , after the third minute of recovery from 102 to 148 , after the fourth minute of recovery from 100 to 139 and after the fifth minute of recovery from 96 to 134 beats per minute, no matter the examined group (Table 3 ).

The lactate concentration values (La), measured after the $3^{\text {rd }}$ minute of recovery upon the finish the tests reached the difference of $3.2 \%$ in the function of examined groups percentagewise, while the generally achieved values ranged from 10.0 to $17.0 \mathrm{mmol} / \mathrm{L}$. After the $5^{\text {th }}$ minute of recovery, lactate concentration values reached the difference of $5.5 \%$ percentagewise, while the achieved values remained within the range from 9.0 to $17.0 \mathrm{mmol} / \mathrm{L}$ no matter the examined group (Table 3 ). 
Specific wrestling preparedness, expressed as index value and in the function of thestandardized model of Specific Judo Fitness Test (SWPT ${ }_{-S \mathrm{~F}} \mathrm{INEX}$ ) the difference of average values on the test from 34.0 $\%$ percentagewise has been achieved in relation to the examined groups, while the generally achieved values of preparedness ranged from 15.5 to 7.4 index values. Specific wrestling performance, where the index value was created according to the new method of indexing (SWPT ${ }_{-\mathrm{NEW}}{ }^{\mathrm{INDEX}}$ ), achieved the difference of average values on SWPT of $24.8 \%$, while the generally achieved values of preparedness ranged from 266.4 to 675.0 index values no matter the examined group (Figure 1, Table 3).

Table 3. Analysis of the differences of the observed parameters in relation to the examined group.

\begin{tabular}{|c|c|c|c|c|c|c|c|c|c|c|c|}
\hline Variables & $\begin{array}{l}\text { Compet. } \\
\text { level }\end{array}$ & Mean & $\begin{array}{l}\text { Std. } \\
\text { Dev. }\end{array}$ & $\begin{array}{l}\text { Std. } \\
\text { Err. }\end{array}$ & Min. & Max. & $\mathbf{F}$ & Sig. & $\mathbf{t}$ & df & $\begin{array}{c}\text { Sig. } \\
\text { (2-tailed) }\end{array}$ \\
\hline \multirow{2}{*}{ SWPT_I_A ${ }^{\text {throwes }}$} & $1^{\text {st }}$ league & 8,10 & 0,57 & 0,18 & 7 & 9 & \multirow{2}{*}{5,192} & \multirow{2}{*}{0,032} & \multirow{2}{*}{4,871} & \multirow{2}{*}{24} & \multirow{2}{*}{0,000} \\
\hline & $2^{\text {nd }}$ league & 6,06 & 1,24 & 0,31 & 4 & 9 & & & & & \\
\hline \multirow{2}{*}{ SWPT_I_B ${ }^{\text {throwes }}$} & $1^{\text {st }}$ league & 7,10 & 0,74 & 0,23 & 6 & 8 & \multirow{2}{*}{0,833} & \multirow{2}{*}{0,371} & \multirow{2}{*}{7,743} & \multirow{2}{*}{24} & \multirow{2}{*}{0,000} \\
\hline & $2^{\text {nd }}$ league & 4,69 & 0,79 & 0,20 & 4 & 6 & & & & & \\
\hline \multirow{2}{*}{ SWPT_I_C ${ }^{\text {throwes }}$} & $1^{\text {st }}$ league & 8,80 & 0,63 & 0,20 & 8 & 10 & \multirow{2}{*}{0,168} & \multirow{2}{*}{0,686} & \multirow{2}{*}{8,897} & \multirow{2}{*}{24} & \multirow{2}{*}{0,000} \\
\hline & $2^{\text {nd }}$ league & 6,13 & 0,81 & 0,20 & 5 & 8 & & & & & \\
\hline \multirow{2}{*}{ SWPT_II_A ${ }^{\text {throwes }}$} & $1^{\text {st }}$ league & 6,10 & 0,32 & 0,10 & 6 & 7 & \multirow{2}{*}{14,088} & \multirow{2}{*}{0,001} & \multirow{2}{*}{7,128} & \multirow{2}{*}{24} & \multirow{2}{*}{0,000} \\
\hline & $2^{\text {nd }}$ league & 4,38 & 0,72 & 0,18 & 3 & 5 & & & & & \\
\hline \multirow{2}{*}{ SWPT_II_B ${ }^{\text {throwes }}$} & $1^{\text {st }}$ league & 5,60 & 0,84 & 0,27 & 4 & 7 & \multirow{2}{*}{0,014} & 00077 & 5624 & 24 & 0000 \\
\hline & $2^{\text {nd }}$ league & 3,63 & 0,89 & 0,22 & 3 & 6 & & 0,907 & 5,034 & 24 & 0,000 \\
\hline SWDT UI Cthrowes & $1^{\text {st }}$ league & 7,90 & 1,10 & 0,35 & 6 & 9 & 1212 & & & & \\
\hline SWRP_II_C & $2^{\text {nd }}$ league & 5,56 & 1,46 & 0,36 & 4 & 9 & 1,242 & 0,276 & 4,340 & 24 & 0,000 \\
\hline throws & $1^{\text {st }}$ league & 43,60 & 2,01 & 0,64 & 40 & 47 & 6037 & 0022 & 7897 & 24 & 0000 \\
\hline $0 \mathrm{VII}-{ }^{1} \mathrm{~N}$ & $2^{\text {nd }}$ league & 30,44 & 4,99 & 1,25 & 24 & 41 & ( & 0,022 & 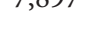 & 24 & 0,000 \\
\hline SWPT I ${ }^{3 \mathrm{~min}}$. & $1^{\text {st }}$ league & 13,50 & 1,96 & 0,62 & 11 & 17 & 0006 & 0939 & 0.560 & 24 & 0.580 \\
\hline Soriteda & $2^{\text {nd }}$ league & 13,07 & 1,88 & 0,47 & 10 & 16 & 0,000 & ( & 0,500 & 24 & 0,500 \\
\hline $5 \min$. & $1^{\text {st }}$ league & 13,61 & 1,70 & 0,54 & 11 & 17 & 0723 & 0404 & 1038 & 24 & 0310 \\
\hline SWVILLd & $2^{\text {nd }}$ league & 12,86 & 1,86 & 0,47 & 10 & 16 & $0, / 23$ & 0,404 & 1,038 & 24 & 0,310 \\
\hline SWPT $\mathrm{HR}^{0 \mathrm{~min} .}$ & $1^{\text {st }}$ league & 183,40 & 4,06 & 1,28 & 175 & 188 & 2875 & 0103 & 1857 & 24 & 0.076 \\
\hline 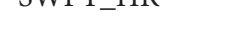 & $2^{\text {nd }}$ league & 187,44 & 6,05 & 1,51 & 175 & 196 & $2,0 / 5$ & 0,100 & $-1,03 /$ & 24 & $0,0 / 0$ \\
\hline SWD7 7 - & $1^{\text {st }}$ league & 166,00 & 6,27 & 1,98 & 153 & 174 & 0484 & 0403 & 2880 & 24 & 0008 \\
\hline SWP1_R & $2^{\text {nd }}$ league & 173,94 & 7,12 & 1,78 & 160 & 184 & 0,404 & 0,490 & $-2,009$ & 24 & 0,000 \\
\hline SUDT HD 2 min. & $1^{\text {st }}$ league & 136,70 & 3,27 & 1,03 & 131 & 143 & 8187 & 0000 & 4678 & 24 & 0000 \\
\hline SWP1_חK & $2^{\text {nd }}$ league & 152,13 & 10,03 & 2,51 & 137 & 167 & $0,18 \gamma$ & 0,009 & $-4,0 / 8$ & 24 & 0,000 \\
\hline swP' & $1^{\text {st }}$ league & 119,00 & 7,94 & 2,51 & 102 & 128 & 680 & 0207 & 92 & 24 & $0031+2>$ \\
\hline SWPI_HR & $2^{\text {nd }}$ league & 128,69 & 11,75 & 2,94 & 105 & 148 & 1,680 & $0,20 /$ & $-2,292$ & 24 & 0,031 \\
\hline SWPT HR Hinin. & $1^{\text {st }}$ league & 114,90 & 5,92 & 1,87 & 100 & 120 & 102 & 0052 & 0 & 24 & 0152 \\
\hline SWVI-IIn & $2^{\text {nd }}$ league & 120,81 & 11,68 & 2,92 & 101 & 139 & 4,183 & 0,052 & $-1,4 / 9$ & 24 & 0,152 \\
\hline SWPT $H_{R}^{5 \min .}$ & $1^{\text {st }}$ league & 110,30 & 6,13 & 1,94 & 96 & 118 & 3233 & 0085 & $-1,340$ & 24 & 0.193 \\
\hline Soritin & $2^{\text {nd }}$ league & 115,63 & 11,53 & 2,88 & 96 & 134 & (2) & 0,000 & (1, & $2 \mathbf{T}$ & ה \\
\hline INDEX & $1^{\text {st }}$ league & 8,03 & 0,46 & 0,15 & 7,4 & 8,9 & 9223 & 0006 & $-6,628$ & 24 & 0.000 \\
\hline SWret & $2^{\text {nd }}$ league & 12,16 & 1,92 & 0,48 & 8,3 & 15,5 & 9,225 & 0,000 & $-0,0<0$ & 24 & 0,000 \\
\hline SWPT INDEX & $1^{\text {st }}$ league & 571,80 & 67,32 & 21,29 & 467,2 & 675 & 0.531 & 0.473 & 4787 & 24 & 0000 \\
\hline $3011-\frac{1}{2}$ & $2^{\text {nd }}$ league & 429,96 & 76,97 & 19,24 & 266,4 & 530,5 & & $0,4 / J$ & $4, / 01$ & 24 & 0,000 \\
\hline
\end{tabular}


In relation to the results of mean value differences of the observed variables in the function of success of the examined groups, statistically significant difference in results in all individual segments of the test has been determined (SWPT_I_A ${ }^{\text {throwes }}$, SWPT_I_B ${ }^{\text {throwes }}$, SWPT_I_C $C^{\text {throwes }}$, SWPT_II_A ${ }^{\text {throwes }}$, SWPT_II_B ${ }^{\text {throwes }}$, SWPT_II_C $\left.C^{\text {throwes }}\right)$, as well as in relation to the total number of throws on the test (SWPT_ $\mathrm{T}_{\mathrm{N}}^{\text {throws }}$ ). Also, significant difference has been determined in both success index variables (SWPT ${ }_{-S \mathrm{~F}}^{\mathrm{INDEX}}$ and SWPT ${ }^{\text {INDEX }}$ ), i.e. quantified specific wrestling preparedness. It should be mentioned that all determined differences of the defined models for calculating the preparedness parameters on the level of statistical significance are from $\mathrm{p}=0.000$ (Figure 1; Table 3). Results of this research have not determined the statistically significant differences of the achieved lactate concentration of the examined groups in the third and fifth minute of recovery, after the SWPT (Table 3 ). Whereas in relation to the functional response of the organism, the difference from the first to the third minute of recovery has been determined, in the function of the examined group (SWPT_HR ${ }^{1 \mathrm{~min} .}: \mathrm{p}=$ 0.008; SWPT_HR ${ }^{2 m i n .}: \mathrm{p}=0.000$; SWPT_HR ${ }^{3 \min }: \mathrm{p}=$ 0.031 ; Table 3).

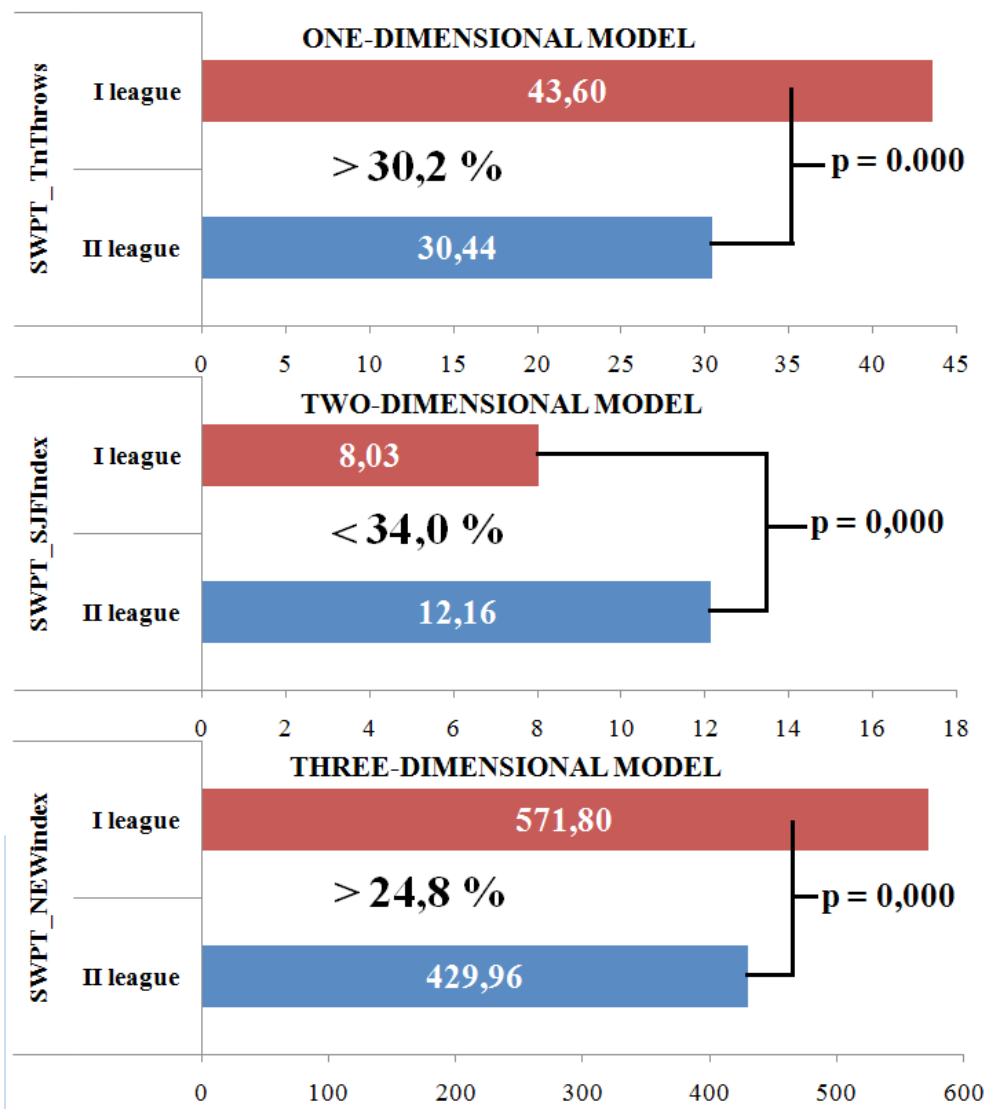

Figure 1. Graphic view of the levels of statistical and in percentage difference of the defined models of calculating preparedness in the function of the examined group 


\section{DISCUSSION}

The test in this research has previously been determined as reliable, and also specific because of its structure. Depending on informational needs and available equipment, one of the models for performance evaluation can be used, and its description of the same characteristic is confirmed (Marković et al., 2017). Based on the results obtained in this research, which aim was to determine the differences in parameters of preparedness of wrestlers that are on different competitive level, the sensitivity of the applied test can be confirmed. In relation to that, upon determining the important metric characteristics of the test, it is possible to realize a continuous system of monitoring the progress of the specific preparedness of every athlete individually, but also to control the applied training methods.

Based on the analysis of the differences of the achieved number of throws as a one-dimensional model of preparedness of the examined groups $\left(1^{\text {st }}\right.$ and $2^{\text {nd }}$ league), statistically significant difference (Table 3; $p=0.000$ ) of result in all individual segments of the test has been determined, as well as in relation to the total number of throws in favor of the $1^{\text {stleague, }}$ which confirms the hypothetical expectations. In comparison to the previous research (Marković et al., 2017), where the examinees achieved the total of 32.68 on average on the SWPT, the identicalness of results with the $2^{\text {nd }}$ league examinees is confirmed, i.e. the better achieved results in favor of $1^{\text {st }}$ league examinees in this research.

By analyzing the metabolic component, i.e. lactate concentration in blood in the third and the fifth minute of recovery, a significant difference between the examined groups has not been determined. In the previous research which dealt with Croatian elite and club wrestlers' organism's metabolic reaction to the load in the mutual control fight, the significant difference of the final sample of lactate values during the post fight recovery hasn't also been determined (Karničić et al., 2009). No matter the time of when the blood sample was taken during recovery, the achieved average values of the achieved lactate concentration were from 12.86 to $13.61 \mathrm{mmol} / \mathrm{L}$, with the measured maximum lactate concentrations that ranged from 16.0 to $17.0 \mathrm{mmol} / \mathrm{L}$. Results show an exceptionally high level of the achieved anaerobic acidosis after the realization of the SWPT. In relation to the testing type, i.e. the nature of physical load, in earlier research it has been determined that the achieved lactate concentrations during the wrestler's recovery after the laboratory and field testings (hand ergometer, bicycle ergometer, treadmill, sandbag test) ranged from 10.6 to $15.1 \mathrm{mmol} / \mathrm{L}$ (Callan et al., 2000; Wright et al., 2015), but with Greco-Roman style wrestlers, the lactate concentration values during recovery after the fight were on the level from 15.8 to $19.1 \mathrm{mmol} / \mathrm{L}$ during all (five) fights (Barbas et al., 2010), i.e. they were on the level between 11.82 and $13.23 \mathrm{mmol} / \mathrm{Lafter}$ a single training control fight (Karninčić et al., 2009). While comparing the obtained results of the lactate concentration with previous research on lactate values in wrestling, the identical values of achieved results have been determined, which can serve as a proof of external validation to the results obtained in this study, i.e. as a proof that the applied variant of the specific wrestling test (SWPT) provoked almost the same specifically competitive load in relation to the metabolic reaction of the organism with highly trained wrestler as well as the fight.

By analyzing the functional values during recovery, from zeroth to the fifth minute after the SWPT, a statistically significant difference of functional response of the organism in the first, second and third minute of recovery has been determined (SWPT $\mathrm{HR}^{1 \text { min. }}$, SWPT_HR ${ }^{2 \text { min. }}$, SWPT_HR ${ }^{3 \mathrm{~min} .}$.) Time structure of a fight simulated on SWPT, as well as the load itself which the more successful competitors are more adapted to ( $1^{\text {st }}$ league) due to higher number of training sessions and competitive performances, could be an answer to the achieved differences of the recovery in favor of the more successful group. The absence of the differences of the achieved pulse frequency immediately upon the finish of the test (SWPT_HR ${ }^{\text {min. }}$ ) can be confirmed in relation to previous research, in which the absence of statistically significant differences in maximum pulse frequency has been determined, with the aim of determining the differences of aerobic characteristics of international and national Serbian wrestlers on treadmill (Štajer et al., 2017). Also, in relation to determining the differences of the achieved maximum pulse frequency, between different weight classes on the same competitive level, a statistically significant difference hasn't been determined on hand ergometer or the sandbag test (Wright et al., 2015).

Functional responses of the organism to the load 
on the SWPT, i.e. immediately upon the finish of the test (SWPT_HR ${ }^{\text {min. }}$ ), is on average 183.40 for the $1^{\text {st }}$ league, that is to say $187.44 \mathrm{bpm}$ for the $2^{\text {nd }}$ league of Serbia. Compared to the previous research in which the wrestlers were examined, it has been determined that they achieve somewhat higher values on the applied test (SWPT) in relation to the bicycle ergometer testing, identical values in relation to the treadmill test, i.e. within the range of the achieved results of the $1^{\text {st }}$ and $2^{\text {nd }}$ league of this research (Callan et al., 2000), somewhat higher values in relation to the hand ergometer test and in relation to the sandbag test (Wright et al., 2015), but also lower values in relation to the wrestlers after the competitive and situational fights (Barbas et al., 2010; Karninčić et al., 2013). These results can also serve as a proof of external validation of the applies test in this research, i.e. as a proof that the applied variant of the specific wrestling test provokes almost the same specifically competitive and training load in relation to the heart reaction of the organism with highly trained wrestler.

Besides the one-dimensional model for calculation wrestlers' preparedness on the afore mentioned tests, multidimensional models have been defined as well. Although the metabolic parameters haven't achieved significant differences between the examined groups, functional parameters have achieved significant differences in three out of six variables that were observed (SWPT_HR ${ }^{1 \text { min. }}$, SWPT_HR ${ }^{2 m i n}$, SWPT_HR ${ }^{3 \mathrm{~min}}$ ), and only one statistically significant different variable of which is included in the calculating models (SWPT_HR ${ }^{\text {min. }}$ ). Index values, as the measure of wrestlers' specific preparedness have shown the high statistically significant difference $(\mathrm{p}=0.000)$ between the examined groups in both multidimensional models of calculating (SWPT ${ }_{\mathrm{F}}^{\text {INDEX }}$ and SWPT ${ }_{-\mathrm{NEW}}{ }^{\text {INDEX }}$ ). In the previous research (Marković et al., 2017), based on IIFDEX, the averagely better result of 11.30 index values has been achieved, and based on ${ }_{\text {NEW }}{ }^{\text {INEX }}$, the averagely better result of 469.80 index values has been achieved on the SWPT. Comparing the results, the $2^{\text {nd }}$ league wrestlers have achieved somewhat worse values in relation to the previous research (Marković et al., 2017), whereas the $1^{\text {st }}$ league wrestlers achieved significantly better results.

If we assume that many different factors are included in a model for calculating the index of pre- paredness, the more precisely, i.e. the better would the performance itself be described, no matter the individual strength of describing the energy, metabolic and functional parameters. In relation to that, the linear growth of the difference of the achieved results in percentages, from $30.2 \%$ in one-dimensional model to $34.0 \%$ in two-dimensional model, goes to show that this statement is valid (Figure 1). The percentual difference of the achieved index of preparedness between the examined groups, from $24.8 \%$ in threedimensional model, represents a proof of individual difference of the way of recovery of the organism of every examinee individually, i.e. significant contribution of the metabolic component in recovery, or in performance deterioration in the next fight that either took place on the same or the following day (Figure 1).

\section{CONCLUSION}

In relation to the aim of the research, and in the function of the model of calculating the parameters of the wrestlers' specific preparedness, the statistically significant difference of the achieved results of preparedness in all three models has been determined. Based on the similar metabolic values of the examined groups, and partial differences in achieving functional values to the same given exertion (SWPT), it can be concluded that the determined differences in all three models for calculating the parameters of preparedness of the examined groups are primarily the consequence of not being well-trained, i.e. of insufficient adaptation for realization of big loads which require high pulse frequency, but also lactate concentration, given time period, but also better use of energy, i.e. economization of movement as the consequence of doing sports for a longer period of time.

The determined significant differences prove that the Specific Wrestling Performance Test, that aims at measuring the specific preparedness of wrestlers (aerobic, anaerobic, metabolic, functional, as well as coordinational abilities) is sensitive to the competitive level and can be applies as a method for evaluating the level of achieved preparedness in wrestling sport.

Further research should be realized with a direct aim of determining the sensitivity of the specific wrestling tests examined, i.e. observing the param- 
eters of preparedness in relation to a higher number of different groups in the function of success on the competition, as well as in relation to different ages and sexes of the wrestlers.

\section{REFERENCES}

1. Arslanoğlu, E., Şenel, O., \& Aydoğmuş, M. (2015). Weight loss and lactic acid relation during wrestling match in elite Greco-Roman wrestlers. International Journal of Physical Education, Sports and Health, 1(4), 01-06.

2. Aschenbach, W., Ocel, J., Craft, L., Ward, C., Spangenburg, E., \& Williams, J. (2000). Effect of oral sodium loading on high-intensity arm ergometry in college wrestlers. Medicine and Science in Sports and Exercise, 32, 669-675.

3. Astrand, P.O., Rodahl, K., Dahl, A.H., \& Stromme, B.S. (2003). Textbook of work physiology - Physiological bases of exercise (Fourth Ed.). Champaign, IL: Human Kinetics.

4. Barbas, I., Fatouros, I.G., Douroudos, I.I., Chatzinikolaou, A., Michailidis, Y., Draganidis, D., Jamurtas, A.Z., Nikolaidis, M.G., Parotsidis, C., Theodorou, A.A., Katrabasas, I., Margonis, K., Papassotiriou, I., \& Taxildaris, K. (2010). Physiological and performance adaptations of elite Greco-Roman wrestlers during a one-day tournament. European Journal of Applied Physiology, 111(7), 1421-1436.

5. Callan, S.D., Brunner, D.M., Devolve, K.L., Mulligan, S.E., Hesson, J., Wilber, R.L., \& Kearney, J.T. (2000). Physiological profiles of elite Freestyle wrestlers. Journal of Strength \& Conditioning Research, 14, 162-169.

6. Cinar, G., \& Tamer, K. (1994). Lactate profiles of wrestles who participated in 32nd European freestyle wrestling championship in 1989. Journal of Sports Medicine and Physical Fitness, 34, 156-160.

7. Dopsaj, M., \& Janković, R. (2014). Validation of specific skills' polygon among students in the academy of criminalistic and police studies:

\section{Acknowledgement}

The paper is a part of the project "Effects of the Applied Physical Activity on Locomotor, Metabolic, Psychosocial and Educational Status of the Population of the Republic of Serbia", number III47015, funded by the Ministry of Education, Science and Technological Development of the Republic of Serbia - Scientific Projects 2011 - 2018 Cycle.

metabolic and functional indicators for exercise. NBP - Journal of Criminalistics and Law, 19(1), 185-199.

8. Franchini, E., Nakamura, F.Y., Takito, M.Y., Kiss, M.A., \& Sterkowicz, S. (1998). Specific fitness test developed in Brazilian judoists. Biology of Sport, $15,165-170$.

9. Hair, J., Anderson, R., Tatham, R., \& Black, W. (1998). Multivariate Data Analysis (Fifth Ed.). Prentice - Hall, Inc., USA.

10. Hart, S., Drevets, K., Alford, M., Salacinski, A., \& Hunt, E.B. (2013). A method comparison study regarding the validity and reliability of the Lactate Plus analyzer. BMJ Open3:e001899.doi:10.1136/ bmjopen-2012-001899.

11. Horswill, C.A. (1992). Applied physiology of amateur wrestling. Sports Medicine, 14(2), 114-143.

12. Houston, M.E., Sharratt, M.T., \& Bruce, R.W. (1983). Glycogen depletion and lactate responses in freestyle wrestling. Canadian Journal of Applied Sport Sciences, 8, 79-82.

13. Hubner-Wozniak, E., Kosmol, A., Lutoslawska, G., \& Bem, E.Z. (2004). Anaerobic performance of arms and legs in male and female Freestyle wrestlers. Journal of Science and Medicine in Sport, 7, 473-480.

14. Hubner-Wozniak, E., Lutoslawska, G., Kosmol, A., \& Zuziak, S. (2006). The effect of training experience on arm muscle anaerobic performance in wrestlers. Human Movement, 7, 147- 152.

15. Karninčić, H., Gamulin, T., \& Nurkić, M. (2013). Lactate and glucose dynamics during a wrestling match - differences between boys, cadets and juniors. Facta universitatis, Physical Education and Sport, 11(2), 125-133. 
16. Karninčić, H., Tocilj, Z., Uljević, O., \& Erceg, M. (2009). Lactate profile during Greco-Roman wrestling match. Journal of Sports Science and Medicine, 8(3), 17-19.

17. Kasum, G., \& Dopsaj, M. (2012). Descriptive profile of body structure of top greco-roman style wrestlers defined with method of multichannel bioelectric impedance. SportLogia, 8(2), 123-131.

18. Kraemer, W.J., Fry, A.C., Rubin, M.R., TriplettMcBride, T., Gordon, S.E., Koziris, L.P., Lynch, J.M., Volek, J.S., MeuVels, D.E., Newton, R.U., \& Fleck, S.J. (2001). Physiological and performance responses to tournament wrestling. Medicine and Science in Sports and Exercise, 33, 1367-1378.

19. Kulandaivelan, S., Verma, S.K., Mukhopadhyay, S., \& Vignesh, N. (2009). Test retest reproducibility of a hand-held lactate analyzer in healthy men. Journal of Exercise Science and Physiotherapy, 5(1), 30-33.

20. Lidor, R., Melnik, Y., Bilkevitz, A., \& Falk, B. (2006). The ten station judo ability test: a test of physical and skill components. Strength and Conditioning Journal, 28, 18-20.

21. Maglischo, E.W. (2003). Swimming Fastest. Champaign, IL: Human Kinetics.

22. Marković, M., Dopsaj, M., Kasum, G., Zarić, I., \& Toskić, L. (2017). Reliability of the two new specific wrestling tests: performance, metabolic and cardiac indicators. Archives of Budo, 13, 409-420.

23. Muller, E., Benko, U., Raschner, C., \& Schwameder, H. (2000). Specific fitness training and test- ing in competitive sports. Medicine and Science in Sports and Exercise, 32(1), 216-220.

24. Nilsson, J., Csergo, S., Gullstrand, L., Tveit, P., \& Refsnes, P.E. (2002). Work-time profile, blood lactate concentration and rating of perceived exertion in the 1998 Greco-Roman wrestling World Championship. Journal of Sports Sciences, 20, 939- 945.

25. Štajer, V., Trivic, T., Rocklicer, R., Madic, D., Ostojic, S., \& Drid, P. (2017). Physical condition profile of Serbian Greco-Roman style wrestlers. Paper presented at the International scientific and professional conference on wrestling: „Applicable research in wrestling" (146-152), Novi Sad: Faculty of sport and physical education, University of Novi Sad; Faculty of sport and physical education, University of Zagreb.

26. Utter, A., Goss, F., Dasilva, S., Kang, J., Suminski, R., Boras, P., Robertos, R., \& Metz, K. (1997). Development of a wrestling-specific performance test. Journal of Strength \& Conditioning Research, 11(2), 88-91.

27. Wright, G.A., Isaacson, M.I., Malecek, D.J., \& Steffen, J.P. (2015). Development and assessment of reliability for a sandbag throw conditioning test for wrestlers. Journal of Strength \& Conditioning Research, 29(2), 451-457.

28. Yoon, J. (2002). Physiological profiles of elite senior wrestlers. Sports Medicine,32(4), 225-233.

29. Zatsiorsky W.M. (1982). Sportivnaja metrologija. [Sports Metrology. In Russian]. Moscow, Physical Education and Sports. 


\section{PREPARACIÓN DE LOS LUCHADORES DE DISTINTO NIVEL COMPETITIVO EVALUADA POR LA APLICACIÓN DE PRUEBA DE TERRENO}

\section{Extracio}

La lucha es el deporte que se caracteriza prevalentemente por los esfuerzos físicos en las zonas energéticas anaeróbico lácticas. El sujeto del presente trabajo son los parámetros de la preparación de luchadores desde el aspecto de su éxito, como también los niveles de las reacciones metabólicas y cardiacas del organismo, seguidas en la prueba de terreno específica. El objetivo de la investigación es establecer las diferencias en nivel de la preparación específica entre los luchadores de distinto nivel competitivo. La muestra estaba compuesta de 26 luchadores, divididos en dos grupos, en relación con el nivel competitivo en que participan, es decir, los 10 participan en la Primera División de Serbia, mientras que los 16 participan en la Segunda División de luchadores de Serbia. La prueba específica de preparación de luchadores (PEPL), consiste de dos segmentos en duración de 3 minutos, que simulan el tiempo de los asaltos en la lucha, y entre los cuales hay una pausa en duración de 30 segundos. Para relativizar la carga en la prueba se utilizaron tres muñecos de luchadores de distinto peso, y la técnica de cintura en puente como el volteo de estándar para todos los examinados. Las diferencias generales son establecidas por MANOVA, mientras que por la prueba $t$ independiente se establecieron las diferencias individuales de todas las variables en función de los grupos examinados. Sobre la base de los resultados, y en función del modelo de cálculo de los parámetros de la preparación específica de los luchadores, se estableció la diferencia estadística significante $(\mathrm{p}=0.000)$ de los resultados de preparación realizados en todos los tres modelos de cálculo (PEPL_UVVolteos, PEPLSJFIndexo y PEPL_nuevoIndexo). Sobre la base de los valores metabólicos similares de los grupos examinados y las diferencias parciales en la realización de los valores funcionales en el mismo esfuerzo establecido (PEPL), se puede concluir que las diferencias establecidas de todos los tres modelos para calcular parámetros de preparación de los grupos examinados son la consecuencia de la adaptación insuficiente para realizar altas cargas, que requieren una alta frecuencia del pulso, como también la concentración de lácticos para dado período de tiempo.

Palabras claves: LUCHA / MEDICIÓN / PRUEBAS EN TERRENO / RECUPERACIÓN / ÍNDICE DEL ÉXITO

Received: 25.02.2018. Accepted: 05.09. 2018. 


\title{
ПРИПРЕМЉЕНОСТ РВАЧА РАЗЛИЧИТОГ ТАКМИЧАРСКОГ НИВОА ПРОЦЕЊЕНА ПРИМЕНОМ ТЕРЕНСКОГ ТЕСТА
}

\author{
Милан Р. Марковић ${ }^{1}$, Горан Касум² ${ }^{2}$ Миливој Допсај ${ }^{2}$, Лазар Тоскић ${ }^{3}$, Иван Зарић$^{1}$ \\ ${ }^{1}$ Универзитет у Београду, Факултет спорта и физичког васпитања, студент ДАС \\ ${ }^{2}$ Универзитет у Београду, Факултет спорта и физичког васпитања \\ ${ }^{3}$ Универзитет у Приштини, Факултет за спорт и физичко васпитање
}

\begin{abstract}
Сажетак
Рвање је спорт кога доминантно карактеришу физичка напрезања у анаеробно лактатним енергетским зонама. Предмет овог рада су параметри припремљености рвача, са аспекта њихове успешности, као и нивоа метаболичке и срчане реакције организма, праћени на специфичном теренском тесту. Циљ истраживања је да се утврде разлике у нивоу специфичне припремљености, између рвача различитог такмичарског нивоа. Узорак чини 26 рвача, подељених у две групе, у односу на такмичарски ниво у којем наступају, тј. 10 наступа у Првој лиги Србије, док 16 наступа у Другој рвачкој лиги Србије. Тест специфичне рвачке припремљености (СРТП), састоји се из два сегмента у трајању од по 3 минута, који временски симулирају рунде у борби, а између којих је одмор у трајању од 30 секунди. Ради релативизовања оптерећења у тесту су коришћене три рвачке лутке различите тежине, а техника предњи појас као стандардно бацање за све испитанике. Генералне разлике утврђене су МАНОВОМ, док су независним т тестом утврђене појединачне разлике свих варијабли, у функцији испитиваних група. На основу резултата, а у функцији модела израчунавања параметара специфичне припремљености рвача, утврђена је статистички значајна разлика $(\mathrm{p}=0.000)$ остварених резултата припремљености у сва три модела израчунавања (СРТП_У бацања, СРТП__индекс и СРТП_нови инЕкс). На основу сличних метаболичких вредности тестираних група, и делимичних разлика у остваривању функционалних вредности на исти задати напор (СРТП), може се закључити да су утврђене разлике сва три модела за израчунавање параметара припремљености испитиваних група последица недовољне адаптираности за реализацију високих оптерећења, која захтевају високу фреквенцију пулса, као и концентрацију лактата, за дати временски период.
\end{abstract}

КљУчне речи: РВАњЕ / МЕРЕЊА / ТЕРЕНСКО ТЕСТИРАҢЕ / ОПОРАВАК / ИНДЕКС УСПЕШНОСТИ

\section{УВОД}

Рвање захтева висок ниво развијености физичких, техничких, тактичких и психолошких способности и вештина (Hubner-Wozniak et al., 2006). Генерално посматрано, у рвању сви енергетски системи раде симултано (аеробни и анаеробни), али наравно, у различитом степену заступљености, што увек зависи од енергетских захтева актуелне техничко-тактичке ситуације у борби (Cinar \& Tamer, 1994; Callan et al., 2000). У ранијим истраживањима је утврђено да се одлучујуће борбе одвијају у зонама максималног и субмаксималног оптерећења рвача (Nilsson et al., 2002; Hubner-Wozniak et al., 2004).

Неки аутори процењују да се чак 90 \% енергетских потреба у рвачкој борби обезбеђује из анаеробних извора, тј. преовладавају углавном анаеробни гликолитички метаболички путеви (Hubner-Wozniak et al., 2006; Karninčić et al., 2009). Као такво, рвање је спорт који доминантно карактеришу физичка напрезања у анаеробним метаболичким енергетским зонама. Анаеробни систем обезбеђује метаболичке услове за кратко 
и брзо испољавање максималне снаге током меча, за изненадна, експлозивна бацања и подизања, али и за вођење борбе субмаксималним и максималним интензитетом, док аеробни систем доприноси способности рвача за одржањем умерених, средњих и малих напора током трајања борбе (Callan et al., 2000). Студије су показале да је генерални физиолошки профил успешних рвача, висока анаеробна снага и капацитет, као и изнад просечна аеробна моћ, висок проценат мишићне масе и високо развијена мишићна снага, изузетна флексибилност, низак проценат масти (Horswill, 1992; Kasum \& Dopsaj, 2012; Yoon, 2002).

Дијагностика физичких карактеристика је важан део процеса контроле утренираности и обуке спортиста јер даје информације о способности коју треба побољшати али и о ефикасности примењеног тренажног процеса (Lidor et al., 2006). Посебна пажња у дијагностици перформансе рвача треба да буде усмерена на анаеробно-лактатне енергетске системе. Као резултат доминантне заступљености овог енергетског система у врхунском такмичарском рвању, постижу се високе до максималне вредности фреквенције пулса (Kraemer et al., 2001). Такође се и акумулира умерена до изузетно висока концентрација лактата (10-20 ммол/Л) након такмичења (Houston et al., 1983; Kraemer et al., 2001) која може да поремети кисело-базну равнотежу, и доведе до погоршања перформанси (Aschenbach et al., 2000). Прећењем ових метаболичких и контрактилних карактеристика код спортиста током интензивног тренинга или такмичења могу се проценити нивои ацидозе и мишићног замора, као и параметри генералне припремљености спортисте (Barbas et al., 2010; Karninčić et al., 2009; Nilsson et al., 2002; Wright et al., 2015).

Метода теренског тестирања омогућава тренерима да провере ниво актуелне припремљености спортисте у односу на специфичне услове оптерећења. Другим речима, специфични тестови представљају приближавање спортске активности контролисаним условима, које је могуће пратити и мерити, а који симулирају временску структуру такмичења, односно борбе, као и оптерећење, метаболичке и срчане напоре који се испољавају током борбе на такмичењу (Maglischo, 2003; Muller et al., 2000; Zatsiorsky, 1982).
У односу на ове аспекте, није могуће пронаћи велики број истраживања која се баве специфичним теренским тестовима у рвању, тј. специфичном припремљеношћу и одговорима организма на задате напоре (Utter et al., 1997; Marković et al., 2017). У односу на доступну публиковану научну литературу, већи број радова изучавао је метаболичке и функционалне реакције организма у реалној рвачкој борби (Karninčić et al., 2009; Barbas et al., 2010; Karninčić et al., 2013; Arslanoğlu et al., 2015), односно у лабораторијским или теренским тестовима, пројектованим у односу на неспецифичне рвачке задатке (Callan et al., 2000; Wright et al., 2015).

Предмет овог рада су параметри припремљености рвача, са аспекта њихове успешности, као и ниво метаболичке и срчане реакције организма на примењеном тесту. Циљ истраживања је да се утврде разлике у нивоу специфичне припремљености, између рвача Прве и Друге рвачке лиге Србије. Различитост нивоа такмичења у коме наступају тестиране групе, немеће очекивање да ће Прва лига остварити бољи резултат од Друге рвачке лиге, тј. потврдити да је физичка припрема врло битан фактор у рвању. Резултати добијени у овом истраживању се могу користити за потребе даљих истраживања, њихова међусобна поређења, као и за унапређење постојећих резултата, односно за потребе унапређивања фундуса општег и специфичног знања у рвачком спорту, и спортској науци уопште.

\section{МЕТОД РАДА}

Као основни метод истраживања, коришћен је метод теренског тестирања. Као основни сазнајни метод примењен је аналитички метод, као и метод индукције. У односу на аналитичке методе, примењен је метод функционалне анализе, ради откривања међусобних релација и повезаности делова испитиваног феномена, као и компаративна анализа, ради упоређивања својстава, сличности и законитости понављања испољених мерених перформанси. 


\section{Узорак истраживања}

Узорак чини 26 рвача мушког пола, подељених у 2 групе, у функцији такмичарске успешности. Од укупног узорка, 10 рвача наступа у Првој лиги Србије - I лига (узраст: 20.0 година; спортски стаж: 8.4 година; број недељних тренинга: 9.2; телесне висине: 176.0 цм; телесне масе: 78.0 кг; БМИ: $25.46 \mathrm{\kappa г} / \mathrm{M}^{2}$; проценат телесне масти: 12.02 $\%$; проценат мишићне масе: $48.94 \%)$, док 16 рвача наступа у Другој лиги Србије - II лига (узраст: 20.4 година; спортски стаж: 5.6 година; број недељних тренинга: 7.0; телесне висине: 180.9 цм; телесне

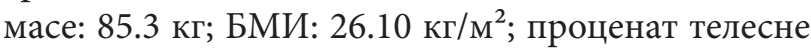
масти: $14.80 \%$; проценат мишићне масе: $49.01 \%$ ). Сви испитаници су били упознати са условима тестирања и добровољно су учествовали у истраживању. Истраживање је реализовано у складу са условима Хелсиншке декларације, а уз одобрење и сагласност Етичке комисије Факултета спорта и физичког васпитања, Универзитета у Београду.

\section{Мерења}

Мерење телесне композиције је обављено коришћењем биоелектричне импеданце (InBodi 720 Biospace, 2008), у јутарњим часовима од 08:00-09:00, и у складу са стандардизованим препорукама произвођача. Након тога уследио је лагани оброк (воће или мањи сендвич, са рехидратацијом) и пауза од сат времена, после које су испитаници тестирани у рвачкој сали. Почетак мерења специфичног теренског теста је био око 10:00 часова пре подне. Наведена тестирања су рађена на Факултету спорта и физичког васпитања, Универзитета у Београду.

За потребе специфичног рвачког теста, сви испитаници су тестирани применом унапред стандардизоване процедуре мерења (Marković et al., 2017), са којом су испитаници упознати на последњем тренингу пре тестирања. На дан тестирања сви испитаници су прошли кроз процес финалног теоријског и практичног упознавањем са процедуром задатака на самом тесту. Пре тестирања претходило је индивидуално опште загревање у трајању од 15 минута, и додатних 5 минута специфичног загревања у виду бацања партнера или рвачке лутке, након чега су имали паузу од 10 минута.

У рвачком тесту коришћена је рвачка лутка као реквизит, а техника предњи појас као стандардно бацање за све испитанике. Ради релативизовања оптерећења, у тесту су корићене три лутке различите тежине по следећем принципу: $\leq 74.9$ кг телесне масе бацала се лутка од 22 кг, од 75.0 до 89.9 кг бацала се лутка од 27 кг, и $\geq 90.0$ кг бацала се лутка од 32 кг (Marković et al., 2017).

Процедура самог тестирања је реализована у форми контролисаног тестовног задатка, преко прецизно маркираних временских задатака и за то је коришћен посебан софтвер, који је програмиран у складу са временском структуром задатака у тесту. Такође, поред аудитивних сигнала који су означавали припрему, почетак и крај теста, испитаници су имали могућност и визуелног приказа и контроле времена, као и приказ назива сваког од сегмента теста. Временску и моторичку структуру теста чинили су временски интервали рада и одмора, као и интензитет рада у складу са шемом приказаном на Табели 1 по следећем принципу:

\section{Тест специфичне рвачке припремљености (СРТП)}

Тест се састоји из два сегмента у трајању од по 3 минута, који временски симулирају рунду у борби, а између којих је одмор у трајању од 30 секунди. Задатак на тесту је следећи: након датог сигнала за почетак теста, испитаник баца лутку, затим је подиже у почетну позицију и одмара до навршених 10 секунди, потом опет реализује бацање, подиже лутку и одмара до навршених 20 секунди, након чега опет реализује бацање и одмара до навршених 30 секунди. Када штоперица откуца 30 секунди креће интензивни део теста где за наредних 20 секунди испитаник има задатак да реализује што већи број бацања; од 50. до 60. секунде испитаник има одмор и спрема се за други минут теста који је у потпуности исти као први; у трећем минуту теста, до 30-е секунде је све исто, након чега испитаник реализује што већи број бацања за 30 секунди, односно до краја трећег минута прве рунде симулације борбе; након тога следи пауза од 30 секунди; друга рунда теста је у потпуности иста као и прва (Marković et al., 2017). Генерални задатак испитаника је да поред извођења задатих појединачних бацања у временским интервалима од 10 секунди, реализује што већи броја бацања у фазама дефинисаним за максималан број бацања. 
Марковић М., и сар., Припремљеност рвача..., ФИЗИЧКА КУЛТУРА 2018; 72 (2): 170-180

Као финална перформанса специфичне радне припремљености узима се укупан број бацања реализован у фазама за извођење максималног броја бацања остварен током целог теста, тј. обе рунде (Табела 1$)$.

Табела 1. Структура теста специфичне рвачке припремљености (Marković et al., 2017)

Структура теста: Специфични рвачки тест припремљености / Трајање теста: 6 минута и 30 секунди

\begin{tabular}{|c|c|c|c|c|c|c|c|c|c|c|c|c|c|c|c|}
\hline Рунде & Минути: & \multicolumn{5}{|c|}{ 1. минут } & \multicolumn{5}{|c|}{ 2. минут } & \multicolumn{4}{|c|}{ 3. минут } \\
\hline \multirow{2}{*}{$\begin{array}{l}\text { Прва } \\
\text { рунда }\end{array}$} & $\begin{array}{c}\text { в. интервали } \\
\text { (сек.) }\end{array}$ & 10 & 10 & 10 & 20 & 10 & 10 & 10 & 10 & 20 & 10 & 10 & 10 & 10 & 30 \\
\hline & Број бацања & 1 & 1 & 1 & Макс. & Одмор & 1 & 1 & 1 & Макс. & Одмор & 1 & 1 & 1 & Макс. \\
\hline \multicolumn{2}{|c|}{ Одмор (сек.) } & & & & & & & & 30 & & & & & & \\
\hline \multirow{2}{*}{$\begin{array}{l}\text { Друга } \\
\text { рунда }\end{array}$} & $\begin{array}{c}\text { в. интервали } \\
\text { (сек.) }\end{array}$ & 10 & 10 & 10 & 20 & 10 & 10 & 10 & 10 & 20 & 10 & 10 & 10 & 10 & 30 \\
\hline & Број бацања & 1 & 1 & 1 & Макс. & Одмор & 1 & 1 & 1 & Макс. & Одмор & 1 & 1 & 1 & Макс. \\
\hline
\end{tabular}

\section{Варијабле}

Поред варијабли које дефинишу број бацања по појединачним сегментима теста (20 сек. предвиђених за максимални броја бацања у првом минуту прве рунде теста - CРТП_I_A 20 сек. предвиђених за максимални броја бацања у другом минуту прве рунде теста - CРТП_I_ $5^{\text {бацања }}, 30$ сек. предвиђених за максимални броја бацања у трећем минуту прве рунде теста СРТП_I_B бацања 20 сек. предвиђених за максимални броја бацања у првом минуту друге рунде теста - CРТП_II_A ${ }^{\text {бацања }} 20$ сек. предвиђених за максимални броја бацања у другом минуту друге рунде теста - СРТП_II_Ббацања 30 сек. предвиђених за максимални броја бацања у трећем минуту друге рунде теста - CРTП_II_B бацања), дефинисан је и укупан број бацања на тесту (СРТП_У бацања) који представља једнодимензионални модел за процену припремљености рвача.

Поред једнодимензионалног модела за процену припремљености, који је са аспекта информационе сложености најједноставнија варијанта израчунавања, коришћена су још два модела као критеријумске варијабле специфичне припремљености.

У дводимензионални модел за израчунавање припремљености (СРТП_- индекС $)$, поред укупног броја бацања улазе и вредности достигнуте фреквенције срца непосредно након и у првом минуту опоравка, чији принцип израчунавања је преузет из Специфичног теста џудо фитнес (Franchini et al., 1998), и израчунава се по следећој формули:

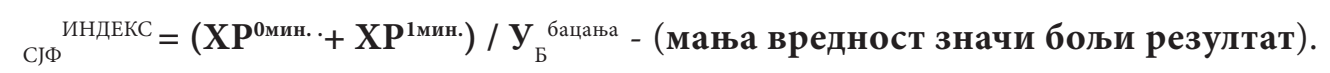

У тродимензионални модел за израчунавање припремљености $($ СРТП_нови индекс $)$, поред укупног броја бацања и вредности достигнутих фреквенција срца, користе се и вредности измерених концентрација лактата у 3 . и 5. минуту опоравка. Овај принцип израчунавања индекса припремљености рвача представља нови модел израчунавања који је публикован од стране Марковић и сарадника (2017), и израчунава се по следећој формули:

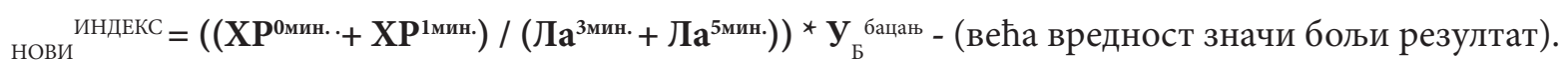

Наравно, праћени су и метаболички и срчани параметри, као засебне варијабле параметара укупног физиолошког напрезања оствареног на тесту (Astrand et al., 2003) и то: 
- концентрација лактата у капиларној крви као мере достигнуте метаболичке ацидозе, у трећем (СРТП_Ла ${ }^{\text {змин. }}$ ) и петом (СРТП_

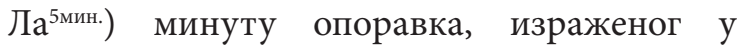
ммол/Л;

- фреквенција пулса као функционалне мере достигнутог оптерећења кардиоваскуларног система, одмах након завршеног теста (СРТП_ХР ${ }^{\text {мин. }}$ ) и у процесу опоравка од првог до петог минута (СРТП_ХР ${ }^{1 м и н ., ~}$ СРТП_ХР 2мин, СРТП_ХР СРТП_ХР

По завршетку теста рвачи су имали 1 минут активног одмора, после чега су заузимали седећу позицију, како би се приступило мерењу постигнуте концентрације лактата у крви и наставило праћење параметара фреквенције срца по стандардизованој процедури. За мерење фреквенције пулса коришћен је „H7 Polar Heart RateSensor“ (Polar, Inc., Lake Success, NY, USA), који је постављан око груди испитаника пре почетка теста. Концентрација лактата анализирана је помоћу преносивог лактатног анализатора нове генерације (Lactate Plus NOVA biomedical, USA), користећи лактатни биосензор заснован на оксидацији лактата (Lactate Methodology - Lactate oxidase biosensor) (Hart et al., 2013; Kulandaivelan et al., 2009). Сви узорци су узимани из капиларне крви, сваки пут из другог прста и то од стране искусног истраживача (Dopsaj and Janković, 2014;
Marković et al., 2017), а за инвазивни део крвног узорка, коришћена је "Unistik 3 Comfort" ланцета за једнократну употребу (Oven Mumford Ltd. UK).

\section{Статистичка обрада и анализа}

Сви резултати су прво анализирани применом основне дескриптивне статистике, где је израчунато следеће: мере централне тенденције (средња вредност варијабли - Mean) и мере дисперзије (стандардна девијација - Std. Dev., стандардна грешка - Std. Err., минимум - Min., максимум - Max.). Генералне разлике између група утврђене су МАНОВОМ, док су независним т тестом утврђене значајне разлике сваке од тестираних варијабли појединачно. Све статистичке анализе су извршене уз помоћ софтверског пакета СПСС 20.0, док је за ниво статистичке значајности разлика коришћена вредност $\mathrm{p}<0.05$ (Hair et al., 1998).

\section{РЕЗУЛТАТИ}

У табели 2 приказани су резултати МАНОВА теста, на основу којих је утврђена генерална разлика параметара припремљености, између испитиваних група различитог такмичарског нивоа.

Табела 2. Резултати разлика на генералном нивоу испитиваних група (МАНОВА)

\begin{tabular}{cccccccc}
\hline $\begin{array}{c}\text { Wilks' } \\
\text { Lambda }\end{array}$ & Value & $\mathrm{F}$ & Hypothesis df & Error df & Sig. & $\begin{array}{c}\text { Noncent. } \\
\text { Parameter }\end{array}$ & $\begin{array}{c}\text { Observed } \\
\text { Power }\end{array}$ \\
\cline { 2 - 8 } & 0,031 & 17,307 & 16,000 & 9,000 & $\mathbf{0 , 0 0 0}$ & 276,908 & 1,000 \\
\hline
\end{tabular}

На основу резултата постигнутих на СРТП, у односу на појединачне минуте теста, тј. предвиђене периоде за максимални број бацања (СРТП_I_A бацања, СТПП_I_Б ${ }^{\text {бацања }}$, CPTП_I_B ${ }^{\text {бацања }}$ CPTП_II_A бацања,

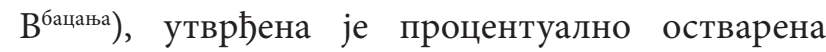
разлика постигнутих резултата у опсегу од $25.2 \%$ до $35.2 \%$ у функцији испитиваних група. У односу на укупан број бацања на тесту (СРТП_У бацања), I лига је остварила већи број бацања за $30.2 \%$ (Графикон 1; Табле 3, I лига $=43.60$ vs II лига $=$ $30.44)$, а генерално остварени резултати на тесту су се налазили у опсегу од 24.0 до 47.0 бацања.

Срчани одговор организма (ХР) на тесту у функцији испитиваних група је остваривао про- центуалне разлике од $2.2 \%$ до $10.1 \%$ фреквенције пулса у односу на праћене варијабле опоравка кардиоваскуларног система. Одговор на задати напор одмах након завршетка теста, био је у опсегу од 175 до 196, након минуте одмора од 153 до 184, након другог минута одмора од 131 до 167, након трећег минута одмора од 102 до 148, након четвртог минута одмора од 100 до 139, и након петог минута одмора од 96 до 134 откуцаја у минуту, без обзира на испитивану групу (Табле 3 ).

Вредности концентрације лактата (Ла) измерених након 3. минута опоравка по завршетку теста су оствариле процентуалну разлику од $3.2 \%$ у функцији испитиваних група, док су генерално постигнуте вредности у опсегу од 10.0 до 17.0 
ммол/Л. Након 5. минута опоравка вредности концентрације лактата достигле су процентуалну разлику од $5.5 \%$, док су остварене вредности остале у опсегу од 9.0 до 17.0 ммол/Л, без обзира на испитивану групу (Табле 3 ).

Испољавање специфичне рвачке припремљености, изражене као индексна вредност, у функцији стандардизованог модела специфичног џудо фитнес теста (СРТП_Сјф индекс) остварена је процентуална разлика просечних вредности на тесту од 34.0 \% уодносу на испитиванегрупе, доксу генерално остварене вредности припремљености у опсегу од 15.5 до 7.4 индексних вредности. Испољавање специфичне рвачке перформансе, где је индексна вредности креирана по новом методу индексирања успешности (СРТП_нови индкс), је остварила процентуалну разлику просечних вредности на СРТП од 24.8 \%, док су генерално остварене вредности припремљености у опсегу од 266.4 до 675.0 индексних вредности без обзира на испитивану групу (Графикон 1; Табле 3 ).

Табела 3. Анализа разлика праћених параметара у односу на испитивану групу

\begin{tabular}{|c|c|c|c|c|c|c|c|c|c|c|c|}
\hline Варијабле & $\begin{array}{l}\text { Takm. } \\
\text { ниво }\end{array}$ & Mean & $\begin{array}{l}\text { Std. } \\
\text { Dev. }\end{array}$ & $\begin{array}{l}\text { Std. } \\
\text { Err. }\end{array}$ & Min. & Max. & $\mathbf{F}$ & Sig. & $\mathbf{t}$ & df & $\begin{array}{c}\text { Sig. } \\
\text { (2-tailed) }\end{array}$ \\
\hline \multirow{2}{*}{ СРТП_I_А бацања } & I лига & 8,10 & 0,57 & 0,18 & 7 & 9 & \multirow{2}{*}{5,192} & \multirow{2}{*}{0,032} & \multirow{2}{*}{4,871} & \multirow{2}{*}{24} & \multirow{2}{*}{0,000} \\
\hline & II лига & 6,06 & 1,24 & 0,31 & 4 & 9 & & & & & \\
\hline \multirow{2}{*}{ СРТП_I_Б бацања } & I лига & 7,10 & 0,74 & 0,23 & 6 & 8 & \multirow{2}{*}{0,833} & \multirow{2}{*}{0,371} & \multirow{2}{*}{7,743} & \multirow{2}{*}{24} & \multirow{2}{*}{0,000} \\
\hline & II лига & 4,69 & 0,79 & 0,20 & 4 & 6 & & & & & \\
\hline \multirow{2}{*}{ СРТП_I_Вбацања } & I лига & 8,80 & 0,63 & 0,20 & 8 & 10 & \multirow{2}{*}{0,168} & \multirow{2}{*}{0,686} & \multirow{2}{*}{8,897} & \multirow{2}{*}{24} & \multirow{2}{*}{0,000} \\
\hline & II лига & 6,13 & 0,81 & 0,20 & 5 & 8 & & & & & \\
\hline \multirow{2}{*}{ СРТП_II_A } & I лига & 6,10 & 0,32 & 0,10 & 6 & 7 & \multirow{2}{*}{14,088} & \multirow{2}{*}{0,001} & \multirow{2}{*}{7,128} & \multirow{2}{*}{24} & \multirow{2}{*}{0,000} \\
\hline & II лига & 4,38 & 0,72 & 0,18 & 3 & 5 & & & & & \\
\hline \multirow{2}{*}{ CРТП_II_Ббацања } & I лига & 5,60 & 0,84 & 0,27 & 4 & 7 & \multirow{2}{*}{0,014} & 907 & 563 & 24 & 0.000 \\
\hline & II лига & 3,63 & 0,89 & 0,22 & 3 & 6 & & 0,907 & 5,034 & 24 & 0,000 \\
\hline СРТП II Вбацања & I лига & 7,90 & 1,10 & 0,35 & 6 & 9 & 242 & 0276 & 240 & 24 & 0000 \\
\hline CP11__ & II лига & 5,56 & 1,46 & 0,36 & 4 & 9 & 242 &, $2 / 6$ & ,340 & 24 & \\
\hline сРТП & I лига & 43,60 & 2,01 & 0,64 & 40 & 47 & 6037 & 0027 & 7807 & 24 & 0000 \\
\hline Cris & II лига & 30,44 & 4,99 & 1,25 & 24 & 41 & $0,03 /$ & 0,022 & 1,891 & 24 & 0,000 \\
\hline СРТП Па Змин. & I лига & 13,50 & 1,96 & 0,62 & 11 & 17 & 0006 & 0939 & 0560 & 24 & 0580 \\
\hline & II лига & 13,07 & 1,88 & 0,47 & 10 & 16 & & & & & \\
\hline СРТП П $a^{5 м и н . ~}$ & I лига & 13,61 & 1,70 & 0,54 & 11 & 17 & 0723 & 0.404 & 1038 & 24 & 03 \\
\hline CP11_ла & II лига & 12,86 & 1,86 & 0,47 & 10 & 16 & $0, / 23$ & 0,404 & 1,038 & 24 & 0,310 \\
\hline СРТП Х $\mathrm{P}^{0 \text { мин. }}$ & I лига & 183,40 & 4,06 & 1,28 & 175 & 188 & 2875 & 0103 & -1857 & 24 & 0076 \\
\hline & II лига & 187,44 & 6,05 & 1,51 & 175 & 196 & & & & & 0,070 \\
\hline p1мин. & I лига & 166,00 & 6,27 & 1,98 & 153 & 174 & 0484 & 0403 & 0 & 4 & \\
\hline CP111_XP & II лига & 173,94 & 7,12 & 1,78 & 160 & 184 & 0,484 & 0,493 & $-2,889$ & 24 & 0,008 \\
\hline СРТП ХР2мин. & I лига & 136,70 & 3,27 & 1,03 & 131 & 143 & 8.187 & 0.009 & -4678 & 24 & 0.000 \\
\hline & II лига & 152,13 & 10,03 & 2,51 & 137 & 167 & & & & & \\
\hline мин. & I лига & 119,00 & 7,94 & 2,51 & 102 & 128 & 680 & 7 & & 24 & \\
\hline U111_Ar & II лига & 128,69 & 11,75 & 2,94 & 105 & 148 & 1,080 & $0,20 /$ & $-2,292$ & 24 & 0,031 \\
\hline СРТП ХРмин. & I лига & 114,90 & 5,92 & 1,87 & 100 & 120 & 4183 & 0.052 & -1479 & 24 & 0152 \\
\hline & II лига & 120,81 & 11,68 & 2,92 & 101 & 139 & & & & & \\
\hline СРТП ХР Гмин. & I лига & 110,30 & 6,13 & 1,94 & 96 & 118 & 3.233 & 0.085 & $-1,340$ & 24 & 0.193 \\
\hline & II лига & 115,63 & 11,53 & 2,88 & 96 & 134 & & & & & \\
\hline СРТП ИНДЕКС & I лига & 8,03 & 0,46 & 0,15 & 7,4 & 8,9 & 9223 & 0006 & -6628 & 24 & 0000 \\
\hline U111 & II лига & 12,16 & 1,92 & 0,48 & 8,3 & 15,5 & Y,L2J & 0,000 & $-0,0<0$ & 24 & 0,000 \\
\hline СРТП & I лига & 571,80 & 67,32 & 21,29 & 467,2 & 675 & 0.531 & 0,473 & 4.787 & 24 & 0,000 \\
\hline CP11_ & II лига & 429,96 & 76,97 & 19,24 & 266,4 & 530,5 & & $0,4 / 3$ & $4, / 0 /$ & 24 & 0,000 \\
\hline
\end{tabular}


У односу на резултате разлика средњих вредности испитиваних варијабли у функцији успешности испитиваних група утврђена је статистички значајна разлика резултата у свим појединачним сегментима теста (СРТП_I_A ${ }^{\text {бацања }}$ CPTП_I_Б ${ }^{\text {бацања }}$, CPTП_I_B ${ }^{\text {бацања }}$, CPTП_II_A ${ }^{\text {бацања }}$ CPTП_II_Б ${ }^{\text {бацања }}$, СРТП_II_B бацања $)$, као и у односу на укупан број бацања на тесту (СРТП_У бацања). Значајна разлика утврђена је и у обе изведене варијабле индекса успешности $($ СРТП-сјФ и СРТП_нови индкс), тј. квантификоване специфичнервачкеприпремљености. Треба напоменути да су све утврђене разлике дефинисаних модела за израчунавање параметара припремљености на нивоу статистичке значајности од $\mathrm{p}=$ 0.000 (Графикон 1; Табела 3). Резултати овог истраживања нису утврдили статистички значајне разлике постигнуте концентрације лактата испитиваних група, у трећем и петом минуту опоравка, након СРТП (Табела 3). Док је у односу на функционални одговор организма утврђена разлика од првог до трећег минута опоравка, у функцији испитиване групе (СРТП_ХР ${ }^{1 м и н .: ~} \mathrm{p}=$ 0.008; СРТП_ХР ${ }^{2 \text { мин.: } \mathrm{p}=0.000 \text {; СРТП_ХР }}$ 0.031; Табле 3).

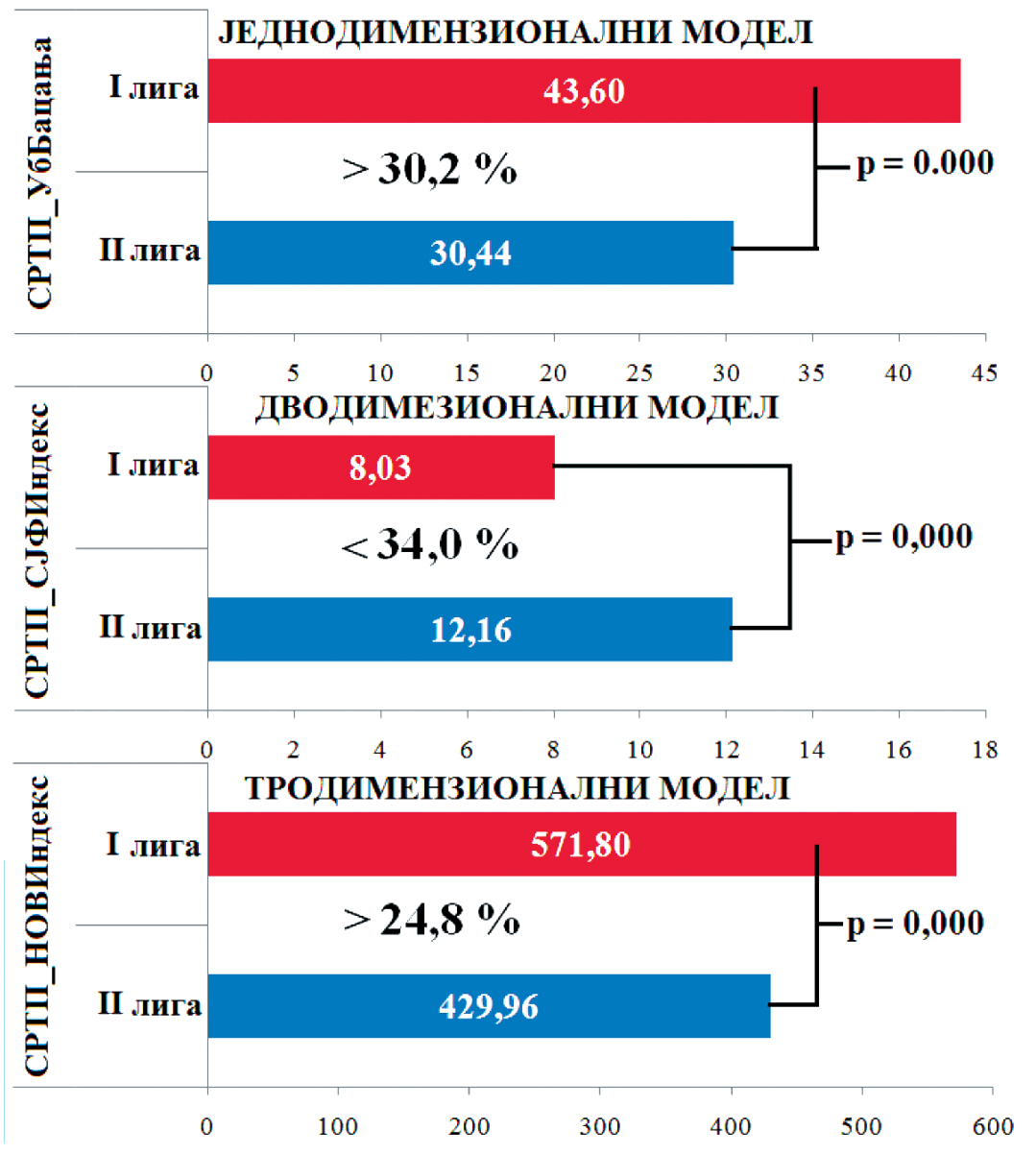

Графикон 1. Графички приказ нивоа статистичких и процентуалних разлика дефинисаних модела израчунавања припремљености у функцији испитиване групе 


\section{ДИСКУСИЈА}

Тест рвачке припремљености, администран у овом истраживању, претходно је утврђен као поуздан и по структури је специфичан. У зависности од информационих потреба и доступне опреме, може се користити као један од модела за процену перформансе, чије описивање је такође потврђено (Marković et al., 2017). На основу резултата овог истраживања, које за циљ има утврђивање разлика параметара припремљености рвача различитог такмичарског нивоа, може се потврдити и осетљивост примењеног теста. С тим у вези, по утврђивању битних метријских карактеристика теста, могуће je реализовати континуирани систем праћења напретка специфичне припремљености сваког спортисте понаособ, али и контролисати примењене методе тренинга.

На основу анализе разлика постигнутог броjа бацања, као једнодимензионалног модела припремљености, испитиваних група (I и II лига), утврђена је статистички значајна разлика (Табела $3 ; \mathrm{p}=0.000)$ резултата у свим појединачним сегментима теста, као и у односу на укупан број бацања, у корист I лиге, што потврђује очекивања самих хипотеза. У поређењу са претходним истраживањем (Marković et al., 2017), чији испитаници су остварили у просеку укупно 32.68 бацања на СРТП, потврђује се индентичност резултата са испитаницима II лиге, тј. бољи остварени резултати у корист испитаника I лиге овог истраживања.

Анализом метаболичке компоненте, тј. концентрације лактата у крви у трећем и петом минуту опоравка, није утврђена значајна разлика међу испитиваним групама. $\mathrm{y}$ претходном истраживању које се бавило метаболичком реакцијом организма хрватских елитних и клупских рвача на оптерећење у међусобној контролној борби, такође није утврђена значајна разлика финалних узорака лактатних вредности у опоравку након борбе (Karničić et al., 2009).

Без обзира на време узетог узорка крви у опоравку, достигнуте просечне вредности остварене концентрације лактата су биле од 12.86 до 13.61 ммол/Л, са измереним максималним концентрацијама лактата, које се налазе у распону од 16.0до 17.0ммол/Л.Резултатиуказујунаизузетно висок ниво достигнуте анаеробне ацидозе након реализације СРТП. У односу на врсту тестирања, тј. природу физичког оптерећења, у ранијим истраживањима је утврђено да се достигнуте концентрације лактата у опоравку рвача након лабораторијских и теренских тестирања (ручни ергометар, бицикл ергометар, тредмил, тест са врећом песка) крећу у опсегу од 10.6 до 15.1 ммол/Л (Callan et al., 2000; Wright et al., 2015); док су вредности концентрације лактата у опоравку након борби код рвача грчко-римским стилом налазе на нивоу од 15.8 до 19.1 ммол/Л током свих (пет) мечева на такмичењу (Barbas et al., 2010), односно налазе се на нивоу између 11.82 до 13.23 ммол/Л након једног тренажног контролног меча (Karninčić et al., 2009). Поређењем добијених резултата концентрације лактата са досадашњим истраживањима лактатних вредности у рвању, утврђене су индентичне вредности постигнутих резултата са скорашњим истраживањима што може да послужи као доказ екстерне валидације резултата добијених у овој студији. Односно, ово је доказ да коришћена варијанта Специфичног рвачког теста (СРТП) провоцира скоро истоветно специфично такмичарско оптерећење у односу на метаболичку реакцију организма код високо тренираних рвача, као и борба.

Анализом функционалних вредности у опоравку, од нултог до петог минута након СРТП, утврђена је статистички значајна разлика функционалног одговора организма у првом, другом и трећем минуту опоравка (СРТП_ ХР ${ }^{1 \text { мин. }}$, СРТП_ХР²мин., СРТП_ХР ${ }^{\text {змин. }}$. Временска структура борбе која се имитира у СРТП, као и само оптерећење на које су успешнији такмичари (I лига) боље адаптирани, због већег броја тренинга и такмичарских наступа, може бити одговор остварених разлика опоравка у корист успешније групе. Одсуство разлика постигнуте фреквенције пулса одмах по завршетку теста (СРТП_ХРОмин.), може се потврдити у односу на претходна истраживања, где је са циљем утврђивања разлика аеробниих карактеристика међународних и националних рвача Србије на тредмилу, утврђено одсуство статистички значајних разлика у максималној фреквенцији пулса (Štajer et al., 2017). Такође, у односу на утврђивање разлика постигнуте максималне фреквенције пулса, између различитих тежинских категорија истог такмичарског нивоа, на ручном 
ергометру и тесту са врећом песка није утврђена статистички значајна разлика (Wright et al., 2015).

Функционални одговори организма на оптерећење у СРТП, тј. одмах по завршеткутеста (СРТП_

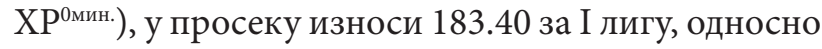
187.44 срчаних откуцаја по минуту за II лигу Србије. Поређењем са ранијим истраживањима у којима су тестирани рвачи, утврђено је да се на примењеном тесту (СРТП) остварују нешто више вредности у односу на тестирање на бицикл ергометру, индентичне вредности у односу на тест на тредмилу, тj. у опсегу остварених резултата I и II лиге овог истраживања (Callan et al., 2000), нешто више вредности у односу на тест на ручном ергометру, и у односу на тест са врећом песка (Wright et al., 2015), али и ниже вредности у односу на рваче након такмичарских и ситуационих борби (Barbas et al., 2010; Karninčić et al., 2013). Ови резултати, такође, могу да послуже као доказ екстерне валидације примењеног теста у овом истраживању, односно као доказ да коришћена варијанта Специфичног рвачког теста провоцира скоро истоветно специфично такмичарскотренажно оптерећење у односу на срчану реакцију организма код високо тренираних рвача.

Поред једнодимензионалног модела за израчунавање припремљености рвача у наведеним тестовима, дефинисани су и вишедимензионални модели. Иако метаболички параметри нису остварили значајне разлике међу испитиваним групама, функционални параметри су остварили значајне разлике у три од шест посматраних варијабли (СРТП_ХР СРТП_ХР 2мин., СРТП_ХР ${ }^{3 м и н .), ~ о д ~ к о ј и х ~ с а м о ~ ј е д н а ~}$ статистички значајно различита варијабла улази у моделе израчунавања (СРТП_ХР ${ }^{1 м и н .) . ~ И з в е д е н е ~}$ индексне вредности, као мере специфичне припремљености рвача, показале су високу статистички значајну разлику $(\mathrm{p}=0.000)$ између испитиваних група у оба вишедимензионална модела израчунавања (СРТП_ индекс и СРТП_

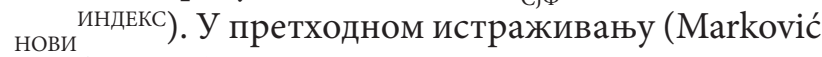
et al., 2017), на основу сјФ индекс-а остварен је просечан бољи резултат од 11.30 индексних вредности, а на основу нови инекс-а остварен је просечан бољи резултат од 469.80 индексних вредности на СРТП. У поређењу резултата, рвачи II лиге су остварили нешто лошије вредности у односу на претходно истраживање (Marković et al., 2017), док су рвачи I лиге остварили знатно боље резултате.

Ако се пође од претпоставке, да што више различитих фактора улазе у неки модел за израчунавање индекса припремљености, тим ће се и сама перформанса прецизније, тј. боље описати, без обзира на појединачну снагу описивања енергетских, метаболичких и функционалних параметара. С тим у вези линеаран раст процентуалне разлике остварених резултата са $30.2 \%$ у једнодимензионалном моделу на 34.0 $\%$ у дводимензионалном моделу, иде у прилог овој тврдњи (Графикон 1). Процентуална разлика оствареног индекса припремљености између испитиваних група, од $24.8 \%$ у тродимензионалном моделу, представља доказ индивидуалне различитости начина опоравка организма сваког испитаника понаособ, односно значајног удела метаболичке компоненте, у опоравку, или у погоршавању испољавања перформанси у наредној борби истог или наредног дана (Графикон 1).

\section{ЗАКЉУЧАК}

У односу на циљ истраживања, а у функцији модела израчунавања параметара специфичне припремљености рвача, утврђена је статистички значајна разлика остварених резултата припремљености у сва три модела. На основу сличних метаболичких вредности тестираних група, и делимичних разлика у остваривању функционалних вредности на исти задати напор (СРТП), може се закључити да су утврђене разлике сва три модела за израчунавање параметара припремљености испитиваних група примарно последица неутренираности, тј. недовољне адаптираности за реализацију високих оптерећења, која захтевају високу фреквенцију пулса, као и концентрацију лактата, за дати временски период, али и секундарно, боље искоришћености енергије, тј. економизације покрета, као последица дужег бављења спортом.

Утврђене значајне разлике упућују да је тест рвачке припремљености мери специфичну припремљеност рвача (аеробних, анаеробних, метаболичких, функционалних, као и координационих способности), да је осетљив на 
такмичарски ниво и да сходно томе може бити примењен као средство за процену нивоа достигнуте припремљености у рвачком спорту.

Даља истраживања треба реализовати са директним циљем утврђивања осетљивости испитиваних специфичних рвачких тестова, тј. посматраних параметара припремљености, у односу на већи број различитих група у функцији успешности на такмичењу (3-4 групе), као и у односу на различити узраст и пол рвача.

\section{ЛИТЕРАТУРА}

1. Arslanoğlu, E., Şenel, O. \& Aydoğmuş, M. (2015). Weight loss and lactic acid relation during wrestling match in elite Greco-Roman wrestlers. International Journal of Physical Education, Sports and Health, 1(4), 01-06.

2. Aschenbach, W., Ocel, J., Craft, L., Ward, C., Spangenburg, E. \& Williams, J. (2000). Effect of oral sodium loading on high-intensity arm ergometry in college wrestlers. Medicine and Science in Sports and Exercise, 32, 669-675.

3. Astrand, P.O., Rodahl, K., Dahl, A.H. \& Stromme, B.S. (2003). Textbook of work physiology Physiological bases of exercise (Fourth Ed.). Champaign, IL: Human Kinetics.

4. Barbas, I., Fatouros, I.G., Douroudos, I.I., Chatzinikolaou, A., Michailidis, Y., Draganidis, D., Jamurtas, A.Z., Nikolaidis, M.G., Parotsidis, C., Theodorou, A.A., Katrabasas, I., Margonis, K., Papassotiriou, I. \& Taxildaris, K. (2010). Physiological and performance adaptations of elite Greco-Roman wrestlers during a oneday tournament. European Journal of Applied Physiology, 111(7), 1421-1436.

5. Callan, S.D., Brunner, D.M., Devolve, K.L., Mulligan, S.E., Hesson, J., Wilber, R.L. \& Kearney, J.T. (2000). Physiological profiles of elite Freestyle wrestlers. Journal of Strength of Conditioning Research, 14, 162-169.

6. Cinar, G. \& Tamer, K. (1994). Lactate profiles of wrestles who participated in 32nd European freestyle wrestling championship in 1989. Journal of Sports Medicine and Physical Fitness, 34, 156-160.

7. Dopsaj, M.\& Janković, R. (2014). Validation of specific skills' polygon among students in the

\section{НАПОМЕНА}

Рад је део пројекта «Ефекти примене физичке активности на локомоторни, метаболички, психосоцијални и образовни статус становништва Републике Србије», број III47015, који финансира Министарство просвете, науке и технолошког развоја Републике Србије - циклус научних пројеката 2011 - 2018.

academy of criminalistic and police studies: metabolic and functional indicators for exercise. NBP - Journal of Criminalistics and Law, 19(1), 185-199.

8. Franchini, E., Nakamura, F.Y., Takito, M.Y., Kiss, M.A. \& Sterkowicz, S. (1998). Specific fitness test developed in Brazilian judoists. Biology of Sport, $15,165-170$.

9. Hair, J., Anderson, R., Tatham, R. \& Black, W. (1998). Multivariate Data Analysis (Fifth Ed.). Prentice - Hall, Inc., USA.

10. Hart, S., Drevets, K., Alford, M., Salacinski, A. \& Hunt, E.B. (2013). A method comparison study regarding the validity and reliability of the Lactate Plus analyzer. BMJ Open 3:e001899.doi:10.1136/ bmjopen-2012-001899.

11. Horswill, C.A. (1992). Applied physiology of amateur wrestling. Sports Medicine, 14(2), 114143.

12. Houston, M.E., Sharratt, M.T. \& Bruce, R.W. (1983). Glycogen depletion and lactate responses in freestyle wrestling. Canadian Journal of Applied Sport Sciences, 8, 79-82.

13. Hubner-Wozniak, E., Kosmol, A., Lutoslawska, G. \& Bem, E.Z. (2004). Anaerobic performance of arms and legs in male and female Freestyle wrestlers. Journal of Science and Medicine in Sport, 7, 473-480.

14. Hubner-Wozniak, E., Lutoslawska, G., Kosmol, A. \& Zuziak, S. (2006). The effect of training experience on arm muscle anaerobic performance in wrestlers. Human Movement, 7, 147- 152.

15. Karninčić, H., Gamulin, T. \& Nurkić, M. (2013). Lactate and glucose dynamics during a wrestling 
match - differences between boys, cadets and juniors. Facta universitatis, Physical Education and Sport, 11(2), 125-133.

16. Karninčić, H., Tocilj, Z., Uljević, O. \& Erceg, M. (2009). Lactate profile during Greco-Roman wrestling match. Journal of Sports Science and Medicine, 8(3), 17-19.

17. Kasum, G. \& Dopsaj, M. (2012). Descriptive profile of body structure of top greco-roman style wrestlers defined with method of multichannel bioelectric impedance. SportLogia, 8(2), 123-131.

18. Kraemer, W.J., Fry, A.C., Rubin, M.R., TriplettMcBride, T., Gordon, S.E., Koziris, L.P., Lynch, J.M., Volek, J.S., MeuVels, D.E., Newton, R.U. \& Fleck, S.J. (2001). Physiological and performance responses to tournament wrestling. Medicine and Science in Sports and Exercise, 33, 1367-1378.

19. Kulandaivelan, S., Verma, S.K., Mukhopadhyay, S. \& Vignesh, N. (2009). Test retest reproducibility of a hand-held lactate analyzer in healthy men. Journal of Exercise Science and Physiotherapy, 5(1), 30-33.

20. Lidor, R., Melnik, Y., Bilkevitz, A. \& Falk, B. (2006). The ten station judo ability test: a test of physical and skill components. Strength and Conditioning Journal, 28, 18-20.

21. Maglischo, E.W. (2003). Swimming Fastest. Champaign, IL: Human Kinetics.

22. Marković, M., Dopsaj, M., Kasum, G., Zarić, I. \& Toskić, L. (2017). Reliability of the two new specific wrestling tests: performance, metabolic and cardiac indicators. Archives of Budo, 13, 409420 .
23. Muller, E., Benko, U., Raschner, C. \& Schwameder, H. (2000). Specific fitness training and testing in competitive sports. Medicine and Science in Sports and Exercise, 32(1), 216-220.

24. Nilsson, J., Csergo, S., Gullstrand, L., Tveit, P. \& Refsnes, P.E. (2002). Work-time profile, blood lactate concentration and rating of perceived exertion in the 1998 Greco-Roman wrestling World Championship. Journal of Sports Sciences, 20, 939- 945.

25. Štajer, V., Trivic, T., Rocklicer, R., Madic, D., Ostojic, S. \& Drid, P. (2017). Physical condition profile of Serbian Greco-Roman style wrestlers. Paper presented at the International scientific and professional conference on wrestling: "Applicable research in wrestling" (146-152), Novi Sad: Faculty of sport and physical education, University of Novi Sad; Faculty of sport and physical education, University of Zagreb.

26. Utter, A., Goss, F., Dasilva, S., Kang, J., Suminski, R., Boras, P., Robertos, R. \& Metz, K. (1997). Development of a wrestling-specific performance test. Journal of Strength \& Conditioning Research, 11(2), 88-91.

27. Wright, G.A., Isaacson, M.I., Malecek, D.J. \& Steffen, J.P. (2015). Development and assessment of reliability for a sandbag throw conditioning test for wrestlers. Journal of Strength \& Conditioning Research, 29(2), 451-457.

28. Yoon, J. (2002). Physiological profiles of elite senior wrestlers. Sports Medicine, 32(4), 225-233.

29. Zatsiorsky W.M. (1982). Sportivnaja metrologija. Moscow: Physical Education and Sports; [in Russian]. 


\title{
МОТОРИЧКЕ СПОСОБНОСТИ И ЕФЕКАТ РЕЛАТИВНЕ СТАРОСТИ АДОЛЕСЦЕНАТА
}

\author{
Игор Вучковић ${ }^{1}$, Александар Кукрић ${ }^{1}$, Александар Гаџић ${ }^{2}$, Борко Петровић ${ }^{1}$, \\ Саша Марковић ${ }^{1}$, Немања Злојутро $^{1}$ \\ ${ }^{1}$ Универзитет у Бањој Луци, Факултет физичког васпитања и спорта, Босна и Херцеговина \\ ${ }^{2}$ Универзитет Сингидунум, Факултет за физичку културу и менаџмент у спорту, Србија
}

\begin{abstract}
Сажетак
Овим истраживањем испитиван је ефекат релативне старости (ЕРС) код адолесцената из Босне и Херцеговине. Циљеви истраживања били су да се процене моторичке способности ученика адолесцентног узраста (мушког и женског пола) и да се испита ЕРС између релативно старијих и релативно млађих ученика, затим између релативно старијих и релативно млађих ученица. Моторичке способности су процењене одабраним тестовима из Еурофит батерије моторичких тестова. Нормалност дистрибуције је проверена Колмогоров-Смирнов тестом, као и показатељима асиметрије (скјуниса) и хомогености (куртозиса) дистрибуције. Код варијабли са нормалном дистрибуцијом, за утврђивање разлика између група испитаника примењена је једнофакторска анализа варијансе, а за варијабле са неправилном дистрибуцијом примењен је Mann-Whitney U тест. Добијени резултати указују да постоје значајне разлике у два теста моторичких способности између релативно старијих и релативно млађих ученика, док код ученица нису утврђене разлике између релативно старијих и релативно млађих испитаница. Резултати указују да је ЕРС мање присутан у средњем адолесцентном узрасту код дечака и девојчица. Ова сазнања могу бити од користи за наставнике физичког васпитања (ФВ) у планирању наставе ФВ.
\end{abstract}

КљУчне речи: ФИЗИЧКО ВАСПИТАҢЕ / СРЕДЊА ШКОЛА / БОСНА И ХЕРЦЕГОВИНА

\section{УВОД}

Ефекат релативне старости (енг. RAE - relative age effect, у даљем тексту ЕРС) привлачи пажњу истраживача у спорту више од 30 година. Barnsley и сарадници (1985) су утврдили да је отприлике $40 \%$ младих хокејаша такмичара исте узрасне категорије аматерских хокејашких лига у Канади (Западна и Онтарио хокеј лига) рођено у прва три месеца године (јануар - март), док је само $10 \%$ спортиста рођено у последња три месеца (октобар - децембар). Током година, овај ефекат примећен је и у другим спортовима: тенис, рагби, фудбал, бејзбол (Cobley et al., 2009). Предности које остварују релативно старији омладинци вероватно потичу од разликау физичкој величини и матурацији (Wattie et al., 2014).

Штавише, аутори су приметили ЕРС у настави физичког васпитања (Bell, et al., 1997; Cobley, et al., 2008), али и другим образовним доменима (McPhillips and Jordan-Black, 2009). Једно од најскоријих истраживања (Nakata et al., 2017) бавило се карактеристикама EPC-a у општој популацији ученика основних и средњих школа у Јапану. Истраживачи су установили значајан ЕРС код дечака узраста од 7 до 15 година у антропометријским и фитнес показатељима, али значајан ЕРС код девојчица је евидентиран само у показатељима фитнеса у основношколском узрасту, али не и у средњошколском узрасту (Nakata et al., 2017).

С обзиром да је значајан део истраживања ЕРС углавном фокусиран на спортски моменат, аутори овог истраживања су желели да провере његов утицај у контексту физичког васпитања (ФВ). 